\author{
J. M. Casas, J. J. Álvaro, S. Clausen, M. Padel, C. Puddu, J. Sanz-López, \\ T. Sánchez-García, M. Navidad, P. Castiñeiras, and M. Liesa
}

\begin{abstract}
In the Pyrenees, the Cambrian-Lower Ordovician strata represent a quiescent time span with no remarkable tectonic activity, followed by a late Early-Mid Ordovician episode of uplift and erosion that led to the formation of the Sardic unconformity. Silurian sedimentation was widespread and transgressive followed by a Devonian succession characterized by a complex mosaic of sedimentary facies. Carboniferous pre-Variscan sediments (Tournaisian-Viséan cherts and limestones) precede the arrival of the synorogenic siliciclastic supplies of the Culm flysch at the Late Serpukhovian. All this succession was subsequently affected by the SerpukhovianBashkirian (Variscan) collision, as a result of which, the Palaeozoic rocks were incorporated into the northeastern branch of the Ibero-Armorican Arc.
\end{abstract}

Coordinators: J. M. Casas, J. J. Álvaro.

J. M. Casas $(\bowtie)$

Departamento de Dinàmica de la Terra i de l'Oceà-Institut de Recerca Geomodels, Universitat de Barcelona, Martí

Franquès s/n, 08028 Barcelona, Spain

e-mail: casas@ub.edu

\section{J. J. Álvaro}

Instituto de Geociencias (CSIC-UCM), Dr. Severo Ochoa 7, 28040 Madrid, Spain

e-mail: jj.alvaro@csic.es

\section{S. Clausen}

UMR 8198 EEP CNRS, Université de Lille 1, Bâtiment SN5, Avenue Paul Langevin, 59655 Villeneuve d'Ascq Cedex, France e-mail: sebastien.clausen@univ-lille1.fr

\section{Padel}

BRGM, 3 Avenue Claude Guillemin, 45100 Orléans, France

e-mail: m.padel@brgm.fr

\section{Puddu}

Departamento de Ciencias de la Tierra, Universidad de Zaragoza, Pedro Cerbuna 12, 50009 Zaragoza, Spain

e-mail: claudiapuddugeo@gmail.com

\subsection{Introduction}

\section{J. M. Casas, J. J. Álvaro}

In the Pyrenees, the aftermath of the late Ediacaran-early Terreneuvian magmatism, related to the Cadomian subduction, records the transition to passive-margin conditions. Cambrian-Lower Ordovician strata represent a quiescent time span with no remarkable tectonic activity, followed by a late Early-Mid Ordovician episode of uplift and erosion that led to the formation of the Sardic unconformity. Uplift was accompanied by magmatic activity that pursuit until the Late Ordovician, the latter coinciding with an extensional pulse that developed normal faults and controlled the record of post-Sardic sediments infilling palaeorelief depressions (the significance of this magmatism and tectonic activity is still

\section{J. Sanz-López}

Dpto. de Geologia, Universidad de Oviedo, Jesus Arias de

Velasco s/n, 33005 Oviedo, Spain

e-mail: jasanz@geol.uniovi.es

\section{T. Sánchez-García}

Departamento Investigación Recursos Geológicos, Área Recursos Minerales y Geoquímica, Instituto Geológico y Minero de España, Ríos Rosas 23, 28003 Madrid, Spain e-mail: t.sanchez@igme.es

\section{Navidad · P. Castiñeiras}

Departamento de Petrología y Geoquímica, Universidad Complutense de Madrid, Novais 12, 28040 Madrid, Spain e-mail: navidad@geo.ucm.es

P. Castiñeiras

e-mail: castigar@ucm.es

M. Liesa

Departament de Mineralogia, Petrologia i Geologia aplicada, Universitat de Barcelona, Martí Franquès s/n, 08028 Barcelona, Spain

e-mail:mliesa@ub.edu 
under debate; see Sect. 8.3). Silurian sedimentation was widespread and transgressive, sealing the Sardic uplift palaeorelief and Late Ordovician rifting pulsation, followed by a Devonian succession characterized by a complex mosaic of sedimentary facies. Tournaisian-Viséan cherts and limestones represent the Carboniferous pre-Variscan sediments, preceding the arrival of the synorogenic siliciclastic supplies of the Culm flysch at the Late Serpukhovian. All this succession was subsequently affected by the SerpukhovianBashkirian (Variscan) collision, as a result of which, the Palaeozoic rocks were incorporated into the northeastern branch of the Ibero-Armorican Arc. In this chapter, we update data and interpretations from these Palaeozoic rocks of the Pyrenees, with a new proposal for the lower Cambrian-Ordovician stratigraphy and an update of the Upper Ordovician, Silurian, Devonian and pre-Variscan Carboniferous stratigraphy. Exposed data emphasize the affinity of the Pyrenean basement rocks with that of the neighbouring Sardinia, Mouthoumet and Montagne Noire-French Central Massif domains, as well as its differences with the Palaeozoic evolution of the Iberian Massif.

In the Pyrenees, the pre-Variscan Palaeozoic rocks constitute a 3-4 km-thick succession that crops out in the backbone of the cordillera (Fig. 8.1). These rocks form an elongated strip unconformably overlain by Mesozoic and Cenozoic rocks, which lie geographically disconnected from neighbouring outcrops of the Catalan Coastal Range to the south, the Mouthoumet and Montagne Noire (southern
French Central) massifs to the north, and Sardinia to the east. Palaeozoic rocks are involved in three main Alpine thrust sheets, the so-called Lower Structural Units (Muñoz 1992) named Nogueres, Orri and Rialp thrust sheets. These units form an antiformal stack with their basal thrusts north-dipping or subvertical in the northern side of the chain, subhorizontal in the central part, and south-dipping in the southern contact with the Mesozoic-Cenozoic cover. In the description that follows, we will focus on the Palaeozoic rocks of the Nogueres and Orri units, which constitute a complete pre-Variscan succession, ranging in age from Cambrian to Carboniferous. Exposures of the Rialp unit only occur in a small tectonic window of the central Pyrenees.

Transverse (N-S-trending) displacement related to the Alpine deformation is about 150-160 km (Muñoz 1992), so the original Palaeozoic basin should be located northward from present-day arrangement. Moreover, the Alpine deformation gave rise to important horizontal axes rotation related to antiformal stack development. In contrast, Alpine metamorphism is absent and internal deformation is moderated. As a result, the original characteristics of the Palaeozoic rocks may be confidently reconstructed in the Pyrenees. As discussed below, other pre-Alpine movements may be also envisaged in order to obtain a reliable original Early Palaeozoic palaeoposition of the Pyrenenan domain and to establish its geodynamic relationship with the neighbouring Variscan Sardinia, Mouthoumet and Montagne Noire-French Central Massif domains.

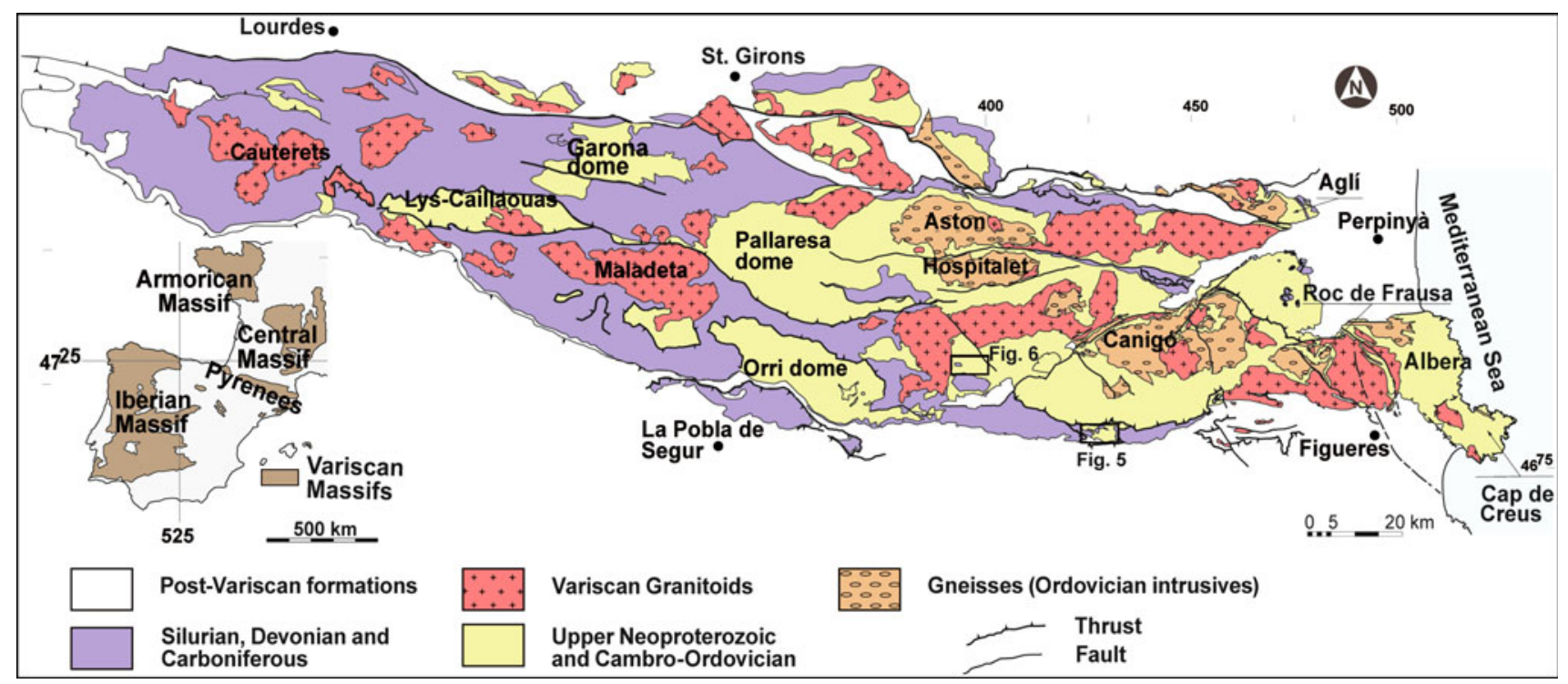

Fig. 8.1 Simplified geological map of the Pyrenees with the location of the massifs mentioned in the text 


\subsection{Cambro-Ordovician (pre-Sardic) Stratigraphy: Jujols Group}

\section{J. J. Álvaro, J. M. Casas, S. Clausen, M. Padel}

The Jujols Group (Fig. 8.2) was firstly described by Cavet (1957) as the Jujols Schists, comprising a monotonous succession of alternating shale and sandstone overlying the Canaveilles Series in the northern Canigó massif. Cavet (1957) attributed an Ordovician age to the Jujols Schists, which then included what is now considered as Upper Ordovician conglomerates and volcanic deposits. These are underlain by a significant erosive unconformity and angular discordance representative of the Sardic Phase, and therefore excluded from the Jujols Group (Laumonier 1988). According to Cavet (1957), the base of the Jujols Schists was characterized by the presence of grey shales with carbonate nodules and quartzite interbeds. As reported in Chap. 2, the Jujols Group overlies the Cadomian volcanic activity reported in the Canaveilles Group.

In this contribution, we follow Padel (2016) and Padel et al. (2018) updating revision of the Jujols Group in the Eastern Pyrenees based on new stratigraphic data and geometric relationships (Fig. 8.2). These authors propose a subdivision of the Jujols Group into the Err, Valcebollère and Serdinya formations. The base of the Jujols Group coincides with the base of the Err Formation (Fig. 8.2), which onlaps an inherited palaeorelief formed by the Pic de la Clape Formation to the south of the Canigó massif (see Chap. 2). Where the Pic de la Clape volcanosedimentary complexes are absent, the Err Formation conformably overlies the Olette Formation. The top of the Jujols Group is highlighted by the Middle-Upper (pars) Ordovician hiatus associated with the Sardic Phase. The thickness of the group can be estimated at about 3-4 km.

The Err Formation (Fig. 8.2) is a relatively monotonous shale-dominated unit, up to about $2000 \mathrm{~m}$ thick. It consists of grey, brownish and greenish shales and centimetre-todecimetre thick, fine-grained sandstones locally punctuated by gravelly sandstones. The latter never exceed $10 \mathrm{~m}$ in thickness and can be observed in the Puigmal area, near the summit of the Puigmal d'Err and at the Pic de la Clapa, where they overlie the Puig Sec Member. These sandstones are also well developed in the Aspres and Conflent areas.

The Valcebollère Formation (Fig. 8.3) consists of a lower massive-to-bedded limestone-to-marble package (up to $300 \mathrm{~m}$ thick), overlain and passing westward to a 15-200 m thick, shale/carbonate alternation that changes upsection into green shales bearing carbonate nodules. The thickness of the formation and its carbonate content diminish northward disappearing to the north of the Canigo massif. Despite the absence of archaeocyaths, several outcrops exhibit typical plano-convex exposures and microbial framebuilding textures (e.g., Gorges de la Fou in the Vallespir-Roc de Frausa area, and isolated bioherms close to Valcebollère village; Fig. 8.3 a-d) characteristic of reefal complexes. In the Aspres area, the Courbis Limestone of the Valcebollère Formation has yielded the acritarch Archaeodiscina cf. umbonulata Volkova, 1968. A. umbonulata is a cosmopolitan species ranging approximately from Cambrian Age 3 to early Cambrian Age 4 (Laumonier et al. 2015; T. Palacios, pers.com. 2016). Associated with the Courbis Limestone, some centimetric layers of grainy phosphorites have been identified, for the first time, marking the topmost part of the Valcebollère Formation.

The Serdinya Formation consists of a roughly $1500 \mathrm{~m}$ thick rhythmic alternation of shale and sandstone beds. Layers are $1 \mathrm{~mm}$ to several $\mathrm{cm}$ thick, change in colour from grey to characteristic light green or light brown grey to greenish, and exhibit sedimentary structures representative of tidal-to-storm influence (Fig. 8.4a). Sandstones up to $1 \mathrm{~m}$ thick occur at the top of the formation, exhibiting graded bedding, load casts and cross bedding (Fontfrède Member) (Fig. 8.4b). The Serdinya Formation conformably overlies the Valcebollère Formation (in some areas sealing hydrothermally induced karstic features, such as in the Roques Blanques section along the road N260; Fig. 8.3e-g) and is topped by the Sardic unconformity (Fig. 8.4c). Acritarchs recovered from the uppermost part of the Serdinya Formation in the southern Canigó massif has yielded a broad Furongian-Early Ordovician microphytoplancton assemblage (Casas and Palacios 2012). Ichnoassemblages recorded in the La Molina area, although not chronostratigraphically diagnostic, show a low-to-moderate ichnodiversity (Gámez et al. 2012). A maximum depositional age of ca. 475 Ma can be proposed for the quartzites of the Fonfrède Member in the La Rabassa dome, on the basis on the youngest detrital zircon population (Margalef et al. 2016).

Considering a Cambrian Fortunian age for the base of the Err Fomation, and a Furongian-Early Ordovician age for the top of the Serdinya Formation (Fig. 8.2), a broad Cambrian-earliest Ordovician age can be envisaged for the entire Jujols Group. As discussed below, it should be noted that Middle Ordovician sedimentary rocks have not yet been described in the Pyrenees.

\subsection{Upper Ordovician Succession}

\section{J. J. Álvaro, J. M. Casas, C. Puddu}

The Upper Ordovician succession of the Central and Eastern Pyrenees, well known after the works of Cavet (1957) and Hartevelt (1970), constitutes a broad fining-upward megasequence bearing a key limestone-marlstone interbed 


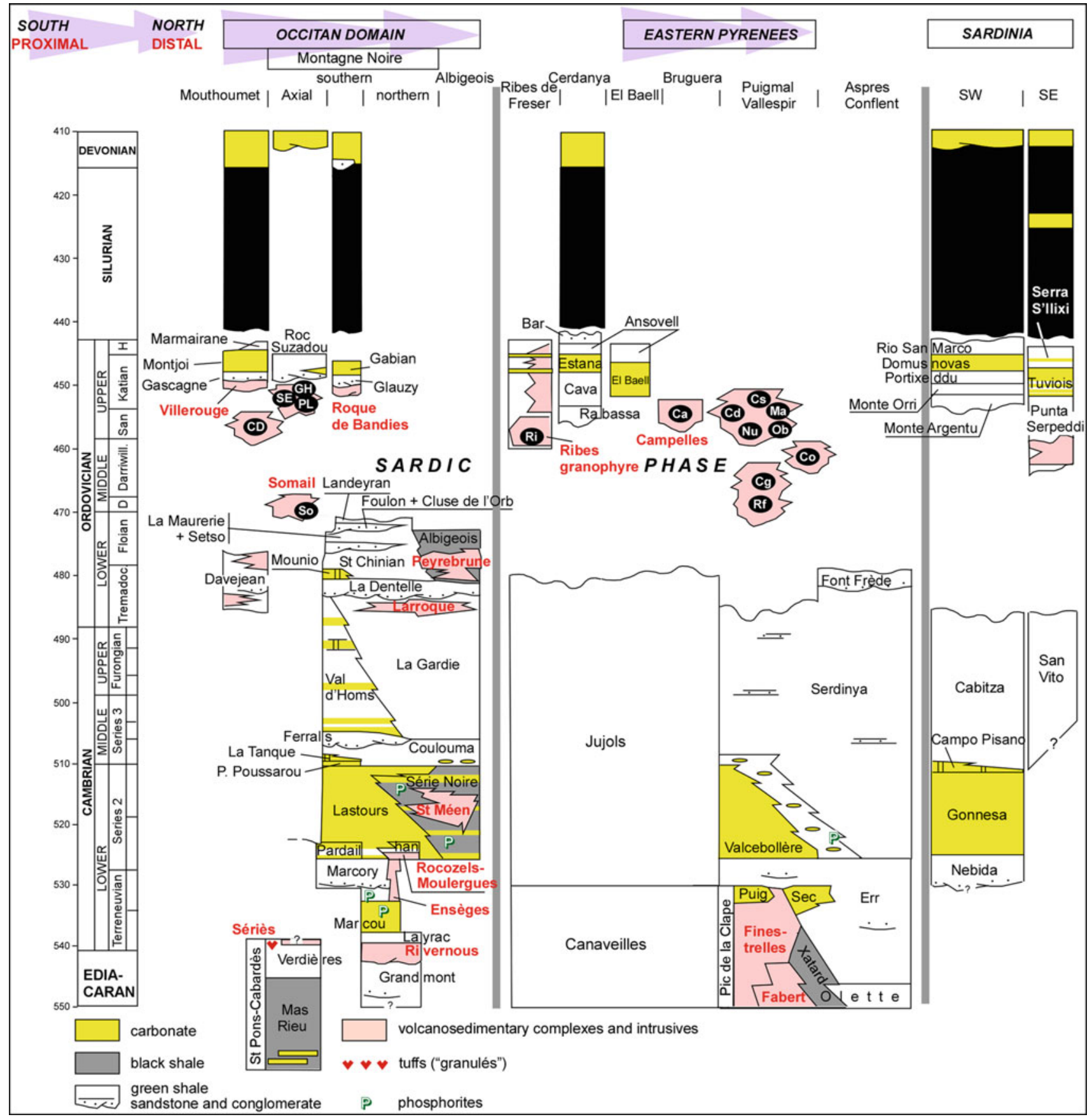

Fig. 8.2 Stratigraphic comparison of the Cambro-Ordovician successions from the Occitan Domain (Montagne Noire and Mouthoumet), Eastern Pyrenees and Sardinia. So: Somail orthogneiss (471 $\pm 4 \mathrm{Ma}$, Cocherie et al. 2005); SE: Saint Eutrope gneiss ( $455 \pm 2 \mathrm{Ma}$, Pitra et al. 2012); GH: Gorges d'Heric orthogneiss (450 $\pm 6 \mathrm{Ma}$, Roger et al. 2004); Pl: Pont de Larn orthogneiss (456 \pm 3 Ma, Roger et al. 2004); Ri: Ribes granophyre (458 $\pm 3 \mathrm{Ma}$, Martínez et al. 2011); Ca: Campelles ignimbrites (ca. 455 Ma, Martí et al. 2014); Cs: Casemí gneiss (446 $\pm 5,452 \pm 5 \mathrm{Ma}$, Casas et al. 2010); Cd: Cadí gneiss (456 $\pm 5 \mathrm{Ma}$, Casas et al. 2010); Ma: Marialles microdiorite (453 $\pm 4 \mathrm{Ma}$, Casas et al. 2010); Nu: Núria gneiss (457 $\pm 4 \mathrm{Ma}$, Martínez et al. 2011); Qb: Queralbs gneiss (457 $\pm 5 \mathrm{Ma}$, Martínez et al. 2011); Co: Cortalets metabasite $(460 \pm 3 \mathrm{Ma}$, Navidad et al. submitted); Cg: Canigó gneiss (472-462 Ma, Cocherie et al. 2005, Navidad et al. 2018); Rf: Roc de Frausa gneiss (477 $\pm 4,476 \pm 5 \mathrm{Ma}$, Cocherie et al. 2005; Castiñeiras et al. 2008) and marked thickness variations, ranging between 100 and $1000 \mathrm{~m}$. Hartevelt (1970) defined five formations, which can be recognized with some lithologic variations all across most part of the cordillera (Fig. 8.2). Furthermore, various volcanic and volcanosedimentary complexes crop out in different areas (Robert and Thiébaut 1976), although 

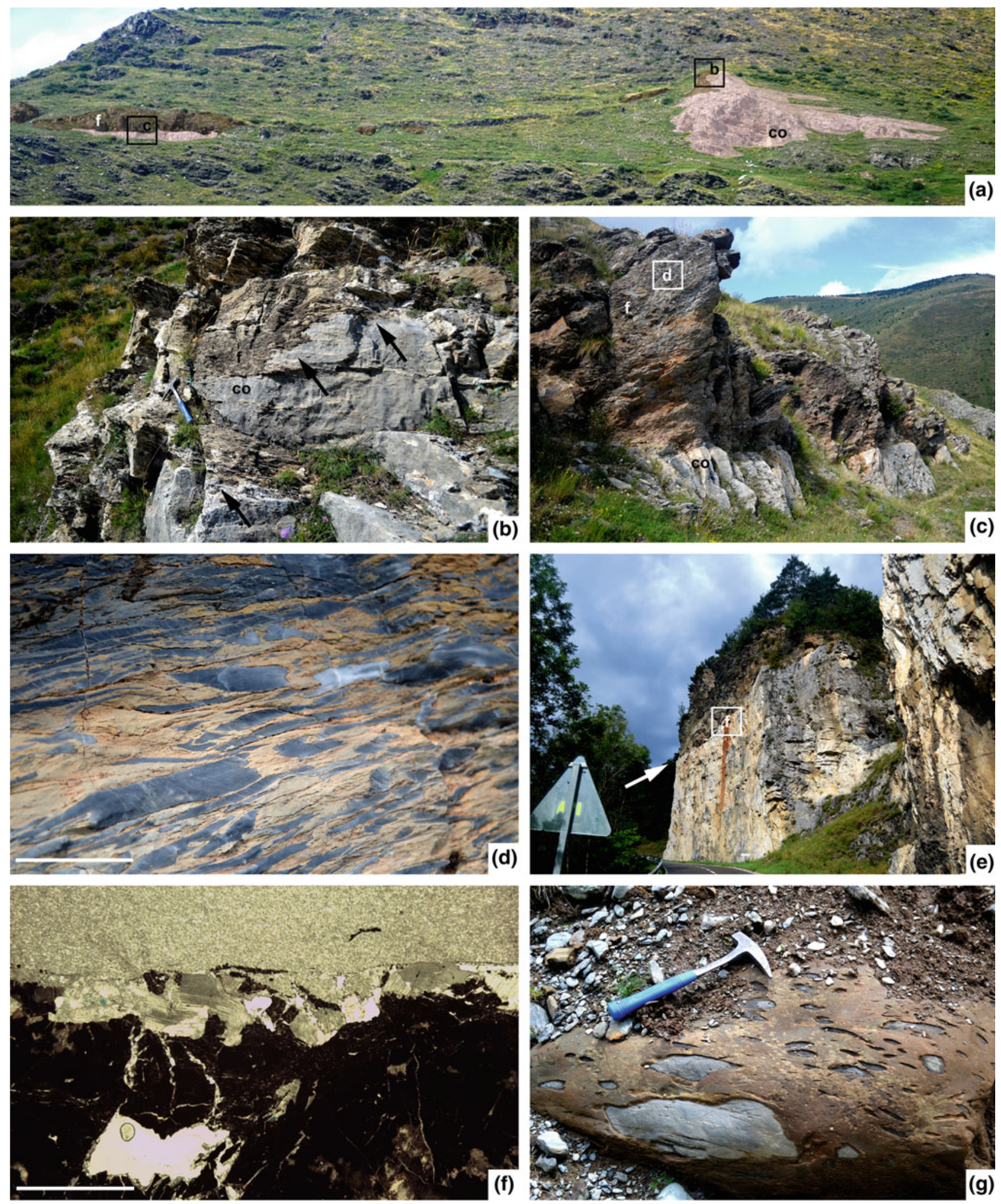

Fig. 8.3 a Field aspect of a hectometre-size, microbial bioherm of the Valcebollère Formation cropping out in the vicinity of the homonymous village; co: core, $f$ : flank. b Detail of boxed area in a showing the intertonguing contact (arrowed) of the core (white) and flank (grey). c Detail of boxed area in a illustrating the distant core/flank contact. d Biohermal flank composed of elongated marble clasts embedded in a silty (brownish) matrix; scale $=4 \mathrm{~cm}$. e Contact (arrowed) of massive marbles (Valcebollère Fm) and bedded sandy shales (Serdinya Fm)

marked by ferrigenous crusts. $\mathbf{f}$ Photomicrograph of the contact marked in e showing a fissure network of hydrothermal veins infilled with hematite, goethite and ankerite sealed (top) by a clean sparry mosaic of calcite (marble); scale $=2 \mathrm{~mm}$. g Valcebollère/Serdinya transition characterized by the presence of unselected marble nodules "floating" in a shaly matrix (facies named "schistes troués" in France and "facies rizada" in Spain) 

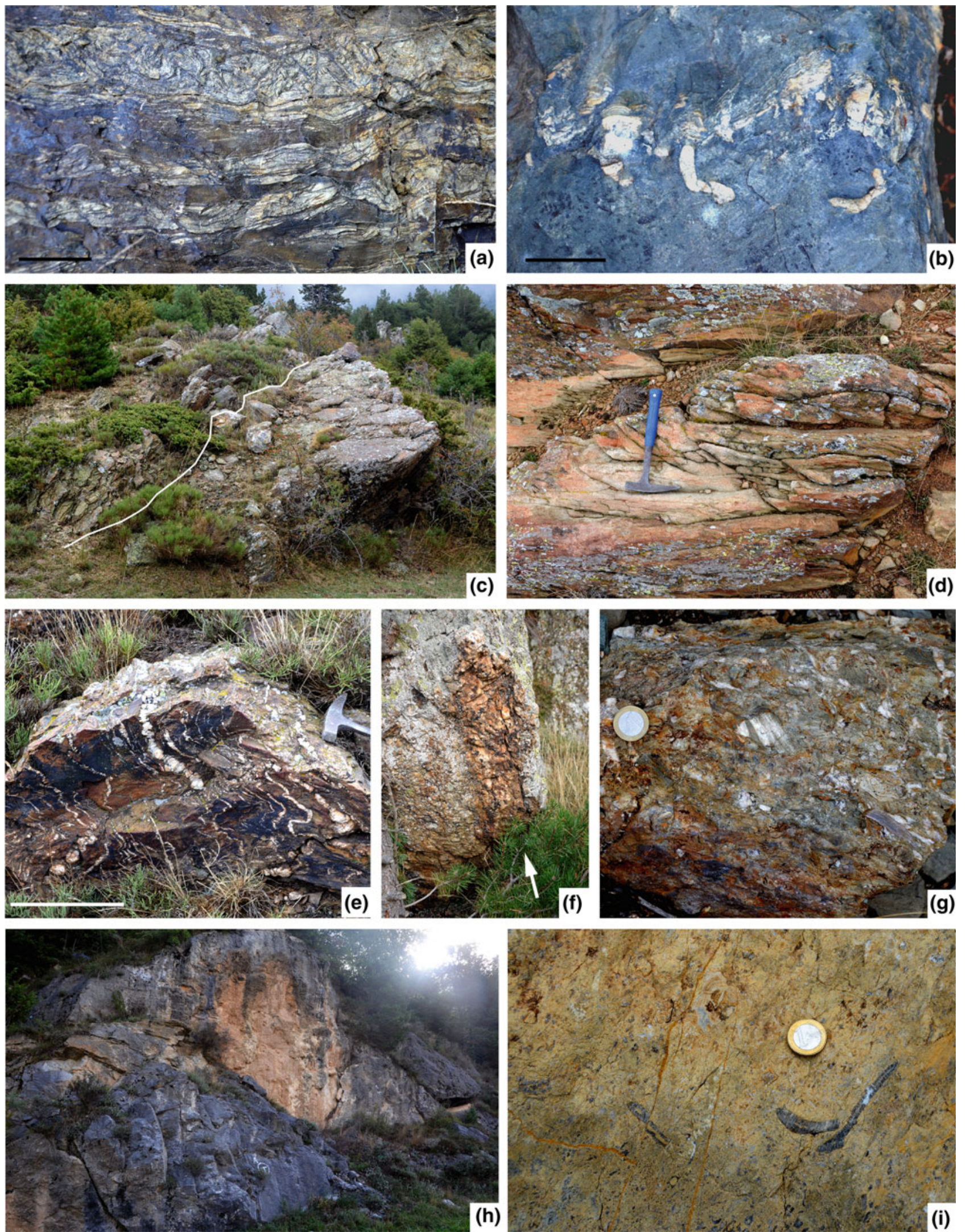
4 Fig. 8.4 a Convoluted alternations of centimetre-thick sandstones and shales showing amalgamation of migrating bars and storm-induced processes; Serdinya Formation at La Molina. b Burrowing surfaces of soft-bodied metazoan suspensivores marking low-sedimentation events; Font Frède Member at Camporells. c Angular discordance separating the Serdinya Formation (left) and the Rabassa conglomerates (right) at Talltendre. d Alluvial-to-fluvial trough cross-stratified conglomerates and sandstones of the Rabassa Formation at Talltendre. e,

radiometric ages are necessary to distinguish between Sardic-related and post-Sardic (Upper Ordovician) volcanogenic events.

Unconformably overlying the Sardic-related palaeotopography, the Rabassa Conglomerate Formation is made up of reddish-purple, unfossiliferous conglomerates with sharp lateral thickness variations, from zero to $200 \mathrm{~m}$. Conglomerates are composed of subrounded to well-rounded clasts rich in slates, quartzites and vein quartz, up to $50 \mathrm{~cm}$ in diameter, embedded in a green-purple granule-sized matrix (Fig. 8.4d). Their massive-to-channelized sets are interpreted as alluvial-to-fluvial deposits (Hartevelt 1970). Due to its stratigraphic position, this author attributed the Rabassa conglomerates to the Sandbian-Early Katian (former Caradoc).

The overlying Cava Formation, 100-800 m thick, which either cover the Sardic unconformity or the Rabassa Conglomerate Formation, is made up of feldspathic conglomerates and sandstones in the lower part, grading upwards into variegated shales and fine-grained sandstones, with strongly burrowed quartzites in the uppermost part (Belaustegui et al. 2016). A contemporaneous volcanic influence is distinct in the southwestern part of the Canigó massif, where ash levels, andesites and metavolcanic rocks are embedded (e.g., in Ribes de Freser; Muñoz 1985). Brachiopods, bryozoans and echinoderms are locally abundant, concentrated in fine-grained sandstones of the middle part of the formation, based on which, Gil-Peña et al. (2004) attributed a Katian (former late Caradoc-early Asghill) age to this formation.

The Estana Formation, which lies above the Cava Formation, consists of limestones and marly limestones, up to $10 \mathrm{~m}$ thick. The unit constitutes a good stratigraphic marker bed, the so-called "schistes troués", "Grauwacke à Orthis" and "Caradoc limestones" of French and Dutch geologists. Conodonts, brachiopods, bryozoans and echinoderms are abundant, yielding a Katian (former mid Ashgill; Gil-Peña et al. 2004) age for the development of echinoderm-bryozoan meadows on shelly, offshore-dominated substrates.

The "Ansovell" Formation (Ansobell sensu Hartevelt 1970) unconformably overlies the Estana limestone and consists of blackish shales with common slumping and convoluted layers close to the base and minor quartzite interlayers in the uppermost part. Where the Estana Formation tapers off, the Ansovell shales directly overlie the Cava sandstones. Finally, the Bar Quartzite Formation marks the top of the Upper Ordovician as a quartzitic layer, 5-10 m thick. An Hirnantian age (former late f Hydrothermal dykes infilled with quartz marking the outlines of the half-grabens infilled with the Rabassa conglomerates at La Molina. g Field aspect of the Rabassa conglomerate rich in subangular hydrothermal quartz clasts; La Molina. h Top of the Katian El Baell Formation at its stratotype unconformably overlain by the Hirnantian Ansovell Formation. i Detail of the El Baell limestones showing echinoderm-rich packstones with scattered, partially articulated columns

Ashgill) was proposed for the Ansovell and Bar formations by Hartevelt (1970), and confirmed by Roqué et al. (2017). Westward, in the Orri, Pallaresa and Garona domes, Gil-Peña et al. $(2000,2004)$ reported a calcareous conglomerate, up to $8 \mathrm{~m}$ thick, directly capping the erosive unconformity that marks the Estana/Ansovell contact, and attributed it to a Hirnantian glacial event.

Thickness of the Upper Ordovician succession diminishes northward, across the Massana anticline and the Aston and Ospitalet domes. In these areas, the Rabassa conglomerates are absent, whereas the Estana limestone attains its maximum thickness, about $70 \mathrm{~m}$ (Margalef 2015).

In the Ribes de Freser area (south of the Canigó massif, Eastern Pyrenees), an Upper Ordovician succession, different from the above-mentioned one, is located. There, several Alpine structural units form an antiformal stack bounded to the north by the out-of-sequence Ribes-Camprodon thrust. In this antiformal stack, three Alpine units (named Ribes de Freser, El Baell and Bruguera) exhibit a characteristic Upper Ordovician succession (Fig. 8.5). Restoration of the Alpine deformation allows us to situate the Bruguera unit in a pre-Alpine northernmost position, the El Baell unit in an intermediate setting, and the Ribes de Freser unit would lie originally in a southernmost one.

The Ribes de Freser unit is predominantly made up of volcanic and volcanosedimentary rocks (Fig. 8.5) (Robert and Thiébaut 1976; Ayora 1980; Robert 1980; Muñoz 1985; Martí et al. 1986), with a variable thickness ranging from 600 to $1200 \mathrm{~m}$. Its lower part consists of dioritic bodies and volcanosedimentary rocks, whereas rhyolitic lava flows and ignimbrites predominate in the central part, and ash levels, ignimbrites and volcaniclastic rocks form its upper part. A granophyric body, dated as $458 \pm 3 \mathrm{Ma}$ (Martínez et al. 2011), intruded into the lower part of the succession. The volcanic activity was mainly explosive and had a calc-alkaline affinity reflecting crustal melting (Martí et al. 1986).

The El Baell unit, in turn, comprises a 300 m-thick succession entirely composed of limestones, marly limestones ("schistes troués") and shales (Robert 1980; Muñoz 1985). Three limestone-dominated thickening-upward sequences, up to $30 \mathrm{~m}$ thick, can be distinguished. Conodonts and crinoids allowed Robert (1980) to attribute an early Katian (former Caradoc) age to the beds forming this unit (Fig. 8.4h, i).

The Bruguera unit lies on the top of the El Baell unit and is composed of a $200 \mathrm{~m}$-thick undated slate-dominated 


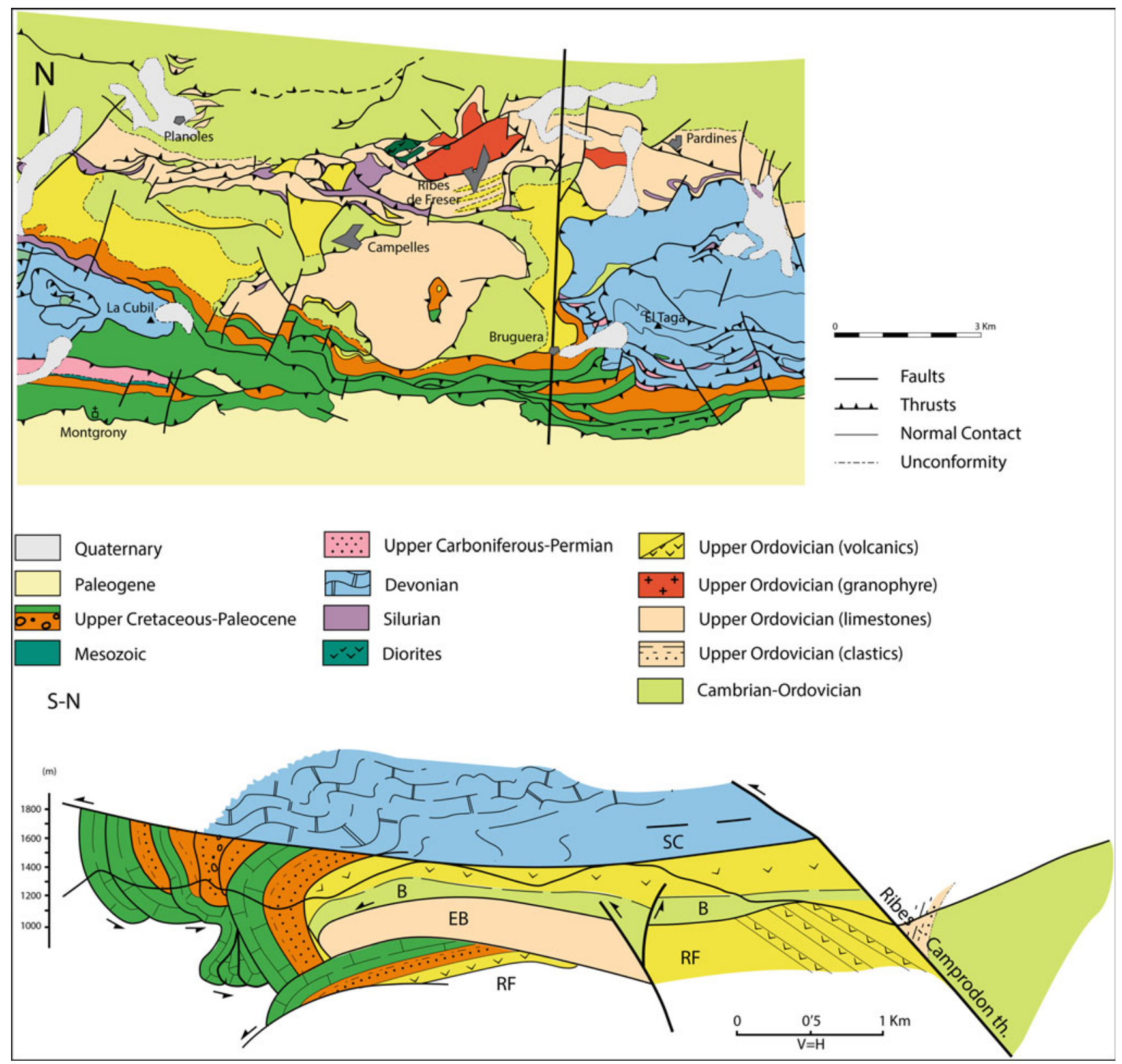

Fig. 8.5 Cross-section of the Freser river antiformal stack with the Ribes de Freser (RF), El Baell (EB) and Bruguera (B) units. After Muñoz (1985) modified. See location on Fig. 8.1

succession, pre-Variscan (Cambrian-Ordovician?) in age, overlain by a volcanic complex (Muñoz 1985). The latter consists of rhyolitic ignimbrites and andesitic lava flows, recently dated at ca. $455 \mathrm{Ma}$ (Martí et al. 2014), an age similar to that of the Ribes granophyre cropping out in the Ribes de Freser unit.

After Santanach's (1972a) work, it is widely accepted that the Upper Ordovician succession lies unconformably over either the Jujols or Canaveilles groups (García-Sansegundo and Alonso 1989; Den Brok 1989; Kriegsman et al. 1989; Poblet 1991; Muñoz and Casas 1996; García-Sansegundo et al. 2004; Casas and Fernández 2007). However, the origin of this unconformity has been object of several interpretations. Santanach (1972a) in the Canigó massif and García-Sansegundo et al. (2004) in the Garona dome attributed the Sardic unconformity to basement tilting, related to of a Late Ordovician faulting episode and subsequent erosion. In the Lys-Caillaouas massif, Den Brok (1989) and Kriegsman et al. (1989) proposed the existence of a pre-Variscan deformation event. A pre-Upper Ordovician folding episode has been also suggested as related to the unconformity on the southern Canigó massif (Casas 2010; Casas et al. 2012). 
However, the meaning of this deformation episode is unclear: it is related neither to metamorphism nor cleavage development, although it seems related to uplift, widespread emersion and considerable erosion before the onset of Upper Ordovician deposition. As a result, the Upper Ordovician rocks directly onlap different formations of the pre-Sardic succession, ranging from the upper Neoproterozoic to the Lower Ordovician in the Central and Eastern Pyrenees (Santanach 1972a; Laumonier and Guitard 1986; Cirés et al. 1994).

Based on the above-reported maximum depositional age of the Jujols Group (ca. $475 \mathrm{Ma}$ ) and the ca. $455 \mathrm{Ma} \mathrm{U}-\mathrm{Pb}$ age for the Upper Ordovician volcanic rocks directly overlying the Sardic unconformity in the Bruguera unit (Martí et al. 2014), a time gap of about 20 m.y. can be estimated for the Sardic Phase. Similar gaps are found in SW Sardinia (ca. 18 m.y.), the type area where the original unconformity was described, where the discontinuity is constrained by well-dated Upper Ordovician metasediments overlying upper Tremadoc-lower Floian(?) strata (Barca et al. 1987; Pillola et al. 2008).

The Sardic uplift (whatever its origin) was necessarily followed by a succession of Late Ordovician extensional pulsations, which preceded and were contemporaneous with the opening of grabens and half-grabens infilled with the alluvial-to-fluvial Rabassa Conglomerate Formation. At outcrop scale, a synsedimentary hydrotermal activity is associated with the onset of decametre-sized normal faults lined with quartz veins and dykes, which subsequently feed the Rabassa conglomerates as vein quartz pebbles (Fig. 8.4 $\mathrm{e}-\mathrm{g}$ ). At cartographic scale, a detailed geological map of the La Cerdanya area reveals a set of normal faults sharply affecting the thickness of the Rabassa and Cava formations (Fig. 8.6) (Casas and Fernández 2007; Casas 2010; Puddu and Casas 2011). The faults are steep and currently exhibit broad N-S to NNE-SSW trending. In most cases, their hangingwall is the eastern block despite the presence of some antithetic faults; maximum throws of about $0.2-0.9 \mathrm{~km}$ can be recognized. Displacement progressively diminishes upward and fades out in the Cava rocks (Fig. 8.6). Based on these orientations, an E-W extension (in present day coordinates) can be proposed. The original orientation of the faults cannot be pinpointed owing to subsequent deformation events, although an original N-S orientation can be proposed. This orientation probably prevented the faults from being inverted during subsequent Variscan and Alpine deformation events, although the faults probably suffered rotations on horizontal E-W axes during these deformation episodes. On the other hand, sharp variations in the thickness of the Upper Ordovician succession have been reported by several authors (Llopis Lladó 1965; Hartevelt 1970; Speksnijder 1986). Hartevelt (1970) documented variations from 200 to more than $850 \mathrm{~m}$ in the thickness of the Cava Formation: e.g., eastward from La Seu d'Urgell, the thickness of the Rabassa and Cava formations attain more than $800 \mathrm{~m}$ before sharply diminishing to some tens of metres within a few kilometres (Casas and Fernández 2007). There, the maximum observed thickness occurs associated with the maximum grain size of the conglomerates (pebbles exceeding $50 \mathrm{~cm}$ in diameter are common). Variations in thickness and grain size can be attributed to palaeorelief formation controlled by fault activity and subsequent erosion of uplifted palaeotopographies, with subsequent infill controlled by alluvial fan and fluvial deposition.

A set of roughly E-W oriented normal faults originally limited the Ribes de Freser, El Baell and Bruguera units, nucleated the contemporaneous active volcanism reported in the Ribes de Freser and Bruguera units, and the high patterns

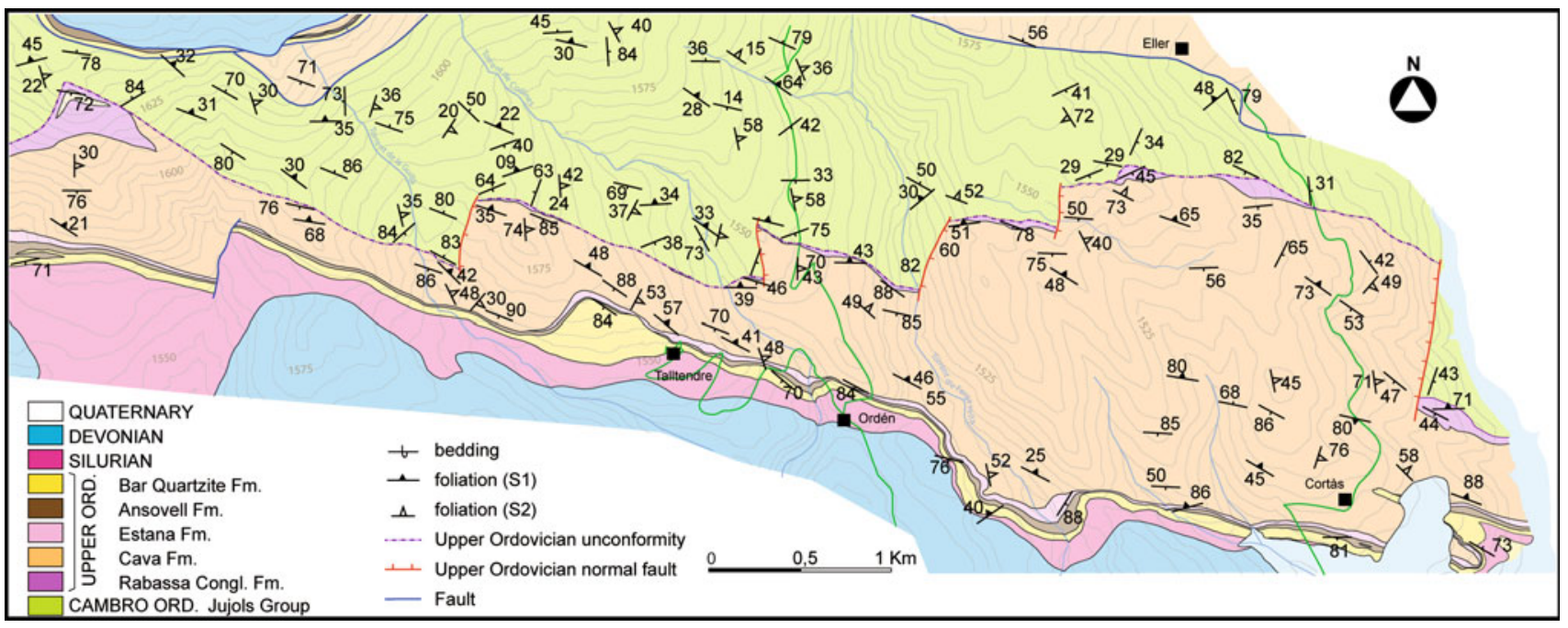

Fig. 8.6 Geological map of the Talltendre area, north of Bellver de Cerdanya; modified from Puddu and Casas (2011). See location on Fig. 8.1 
of Katian carbonate productivity on an unstable epeiric platform, now preserved in the El Baell unit. These E-W oriented faults seemingly coexisted with the aforementioned $\mathrm{N}-\mathrm{S}$ normal faults. The former faults were probably inverted during subsequent Variscan and Alpine tectonics, whereas the latter ones, because of their unfavourable orientation, are preserved and currently recognizable.

\subsection{Ordovician Magmatism}

\section{J. J. Álvaro, J. M. Casas, C. Puddu, T. Sánchez-García, M. Navidad, P. Castiñeiras, M. Liesa}

Successive Ordovician magmatic pulsations are well documented in the pre-Variscan basement of the Pyrenees (Fig. 8.1). According to radiometric data, magmatism lasted about 30 m.y., from ca. 477 to $446 \mathrm{Ma}$. Although the magmatic activity seems to be continuous, two peaks can be distinguished at 473-472 Ma and $457 \mathrm{Ma}$ (Fig. 8.7). Based on geochronological and geochemical data, two different magmatic complexes can be distinguished: latest Early-Mid Ordovician and Late Ordovician in age.

\section{(i) Latest Early and Mid Ordovician magmatism}

During Early to Mid Ordovician times, the magmatic activity gave rise to the intrusion of voluminous aluminous granites, about $500-3000 \mathrm{~m}$ in size and emplaced into the Canaveilles and Jujols strata. They constitute the protoliths of the large laccolithe-shaped, orthogneissic bodies that crop out at the core of the domal massifs that punctuate the

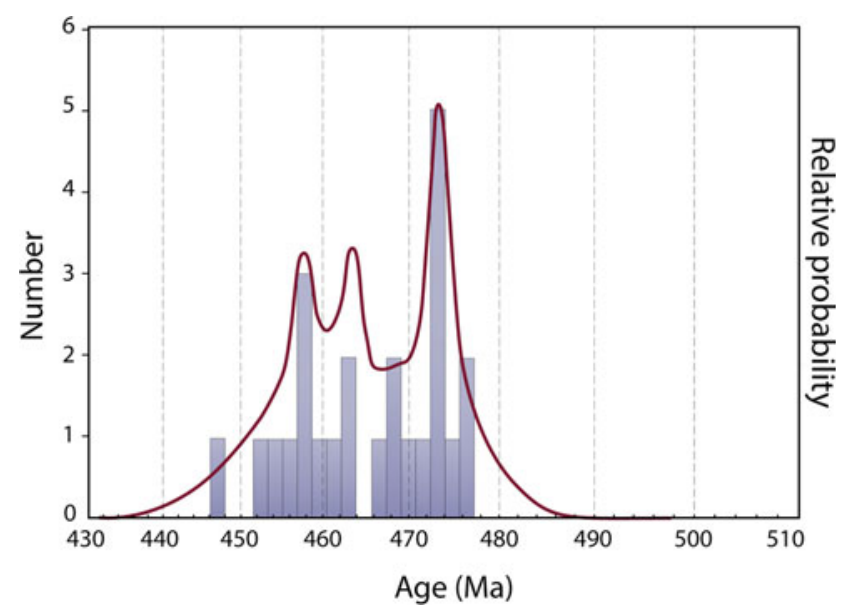

Fig. 8.7 Relative probability plot of the geochronological ages of the Ordovician magmatism of the Pyrenees. Data after Deloule et al. (2002); Cocherie et al. (2005); Castiñeiras et al. (2008); Denèle et al. (2009); Casas et al. (2010); Liesa et al. (2011); Martínez et al. (2011); Mezger and Gerdes (2016); Navidad et al. (2018) and Liesa et al. (unpublsh.). $\mathrm{n}=25$ backbone of the Pyrenees. These are, from west to east, the Aston (470 $\pm 6 \mathrm{Ma}$, Denèle et al. 2009; $467 \pm 2 \mathrm{Ma}$, Mezger and Gerdes 2016), Hospitalet (472 \pm 2 Ma, Denèle et al. 2009), Canigó (472 \pm 6 to $467 \pm 7 \mathrm{Ma}$, Cocherie et al. 2005), Roc de Frausa (477 \pm 4 Ma, Cocherie et al. 2005; $476 \pm 5 \mathrm{Ma}$, Castiñeiras et al. 2008) and Albera (470 \pm 3 Ma, Liesa et al. 2011) massifs (Fig. 8.8), which exhibit a dominant Floian-Dapingian age. It should be noted that only a minor representation of basic coeval magmatic rocks are exposed (e.g., Cortalet metabasite). The acidic volcanic equivalents have been reported in the Albera massif, where subvolcanic rhyolitic porphyroid rocks yielded similar ages than those of the main gneissic bodies: $465 \pm 4,472 \pm 3,473 \pm 2$ and $474 \pm 3$ Ma (Liesa et al. 2011; Liesa unpubl.). Other acidic products are represented by the rhyolitic sills of Pierrefite (Calvet et al. 1988) (Fig. 8.8). Granites are medium to coarse grained and exhibit porphyritic textures with rapakiwi K-feldspars.

The rocks selected for geochemical analysis have suffered from variable degrees of metamorphism and hydrothermalism, so only the most inmobiles elements have been taken into account. We have differentiated three geochemical assemblages: the Cortalets metabasite, the Volcanic Assemblage A and the Gneissic Assemblage A. Some of the differentiated assemblages are based on very few samples and further sampling could modify the geochemical signature documented below.

The Cortalets metabasite (Metabas A in Fig. 8.9) shows low silica content (43.22\%) and high $\mathrm{FeO}_{\mathrm{t}}(10.05), \mathrm{MgO}$ $(9.43 \%)$ and $\mathrm{CaO}(12.16 \%)$ values. It is metaluminous $(\mathrm{A} / \mathrm{CNK}=0.64)$ and subalkaline in the Pearce's diagram (1996) (Fig. 8.9a). REE patterns present slightly more fractionated values for LREE $\left(\mathrm{La}_{n} / \mathrm{Sm}_{\mathrm{n}}=1.54\right)$ than HREE $\left(\mathrm{Gd}_{\mathrm{n}} / \mathrm{Yb}_{\mathrm{n}}=1.19\right)$, without $\mathrm{Eu}$ anomalies and an almost flat arrangement for HREE (Fig. 8.10a). This suggests the lack of plagioclase fractionation and garnet in the melt. $\mathrm{Nb}, \mathrm{Sr}$ and $\mathrm{Ti}$ positive anomalies are distinct in the spider-diagram of Palme and O'Neil (2004) (Fig. 8.10b) reflecting the possible influence of mantle-derived magmas lacking plagioclase and magnetite in the melt. The metabasite exhibits average values of $\mathrm{La} / \mathrm{Nb}$, (average $=0.54), \mathrm{Th} / \mathrm{Nb}(0.06), \mathrm{Th} / \mathrm{La}(0.12)$, $\mathrm{Nb} / \mathrm{Y}$ (0.60), $\mathrm{Zr} / \mathrm{Nb}$ (5.89) and $\mathrm{Nb} / \mathrm{Yb}$ (5.81) close to the Lower Continental Crust parameters of Rudnick and Gao (2004), and $\mathrm{Th} / \mathrm{Yb}$ (average $=0.37$ ) values close to the Ocean Island Basalt of Sun and McDonough (1989) (Fig. 8.11a). In the Wood's (1980) tectonic discrimination diagram, the analysis plots in the arc-basalt domain (Fig. 8.12a), while the Pearce's (2008) diagram informs about crustal contamination (Fig. 8.12b). The $\mathrm{TiO}_{2} / \mathrm{Yb}$ versus $\mathrm{Nb} / \mathrm{Yb}$ diagram (Fig. 8.12c) shows E-MORB character. All geochemical characteres may reflect primitive mantle-derived melts with crustal contamination at their origin. Further samples are necessary to confirm this interpretation. 


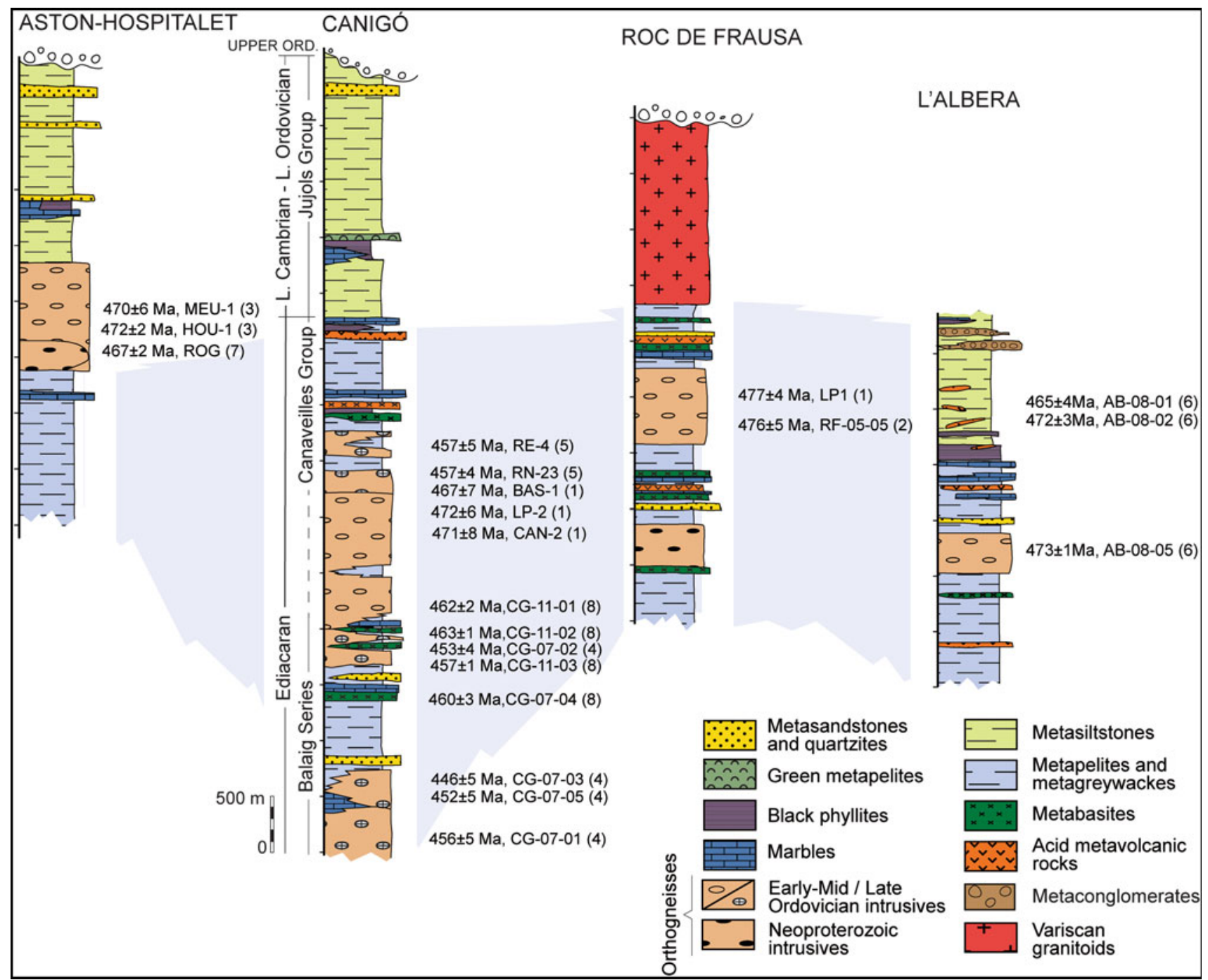

Fig. 8.8 Synthetic stratigraphic logs of the pre-Upper Ordovician rocks from the Aston-Hospitalet, Canigó, Roc de Frausa and Albera massifs with the location of the geochronological data of the protoliths of the Ordovician gneisses: (1) Cocherie et al. (2005); (2) Castiñeiras et al. (2008); (3) Denèle et al. (2009); (4) Casas et al. (2010);

The Volcanic Assemblage A includes 6 samples from the Albera (Liesa et al. 2011) and Pierrefite (Calvet et al. 1988) massifs. They show a narrow range of $\mathrm{SiO}_{2}$ content $\left(70.09<\mathrm{SiO}_{2}<74.87\right)$ and peraluminous $(\mathrm{A} / \mathrm{CNK}=$ $2.03-1.12$ ) and subalkaline features, with an average content of $\mathrm{Nb} / \mathrm{Y}=0.32$ (Fig. 8.9a). REE patterns present more fractionated values for LREE $\left(\mathrm{La}_{\mathrm{n}} / \mathrm{Sm}_{\mathrm{n}}=2.63\right)$ than HREE $\left(\mathrm{Gd}_{\mathrm{n}} / \mathrm{Yb}_{\mathrm{n}}=1.32\right)$ being $(\mathrm{La} / \mathrm{Yb})_{\mathrm{n}}=5.88$. The average Eu anomalies show moderate negative values (0.68) reflecting plagioclase crystallization (Fig. 8.10c). It should be noted that this assemblage presents two subsets, one with a distinct enrichment in HREE and a flat slope, and another with a moderate slope in HREE. This suggests different magmatic
(5) Martínez et al. (2011); (6) Liesa et al. (2011); (7) Mezger and Gerdes (2016) and (8) Navidad et al. (2018). Stratigraphic data from Guitard (1970), Santanach (1972b), Ayora and Casas (1986), Liesa and Carreras (1989) and Liesa et al. (2011)

sources for both subsets. In the spider-diagram of Palme and O'Neil (2004), they show negative anomalies of $\mathrm{Nb}, \mathrm{Sr}$ and Ti (Fig. 8.10d). The overall chondrite-normalized pattern is close to the values of the Upper Continental Crust of Rudnick and Gao (2004), and display slight enrichments in $\mathrm{Th} / \mathrm{Nb}$ (average $=1.13$ ) and $\mathrm{Th} / \mathrm{La}$ (average $=0.56$ ), and depletion in $\mathrm{La} / \mathrm{Nb}$ (average $=2.43), \mathrm{Th} / \mathrm{Yb}$ (average $=3.50$ ) and $\mathrm{Nb} / \mathrm{Yb}$ (average $=3.06$ ) ratios close to EMORB values (3.5 values of Sun and McDonough 1989) (Fig. 8.11b). In the tectonic diagram of Pearce et al. (1984), the samples plot in the volcanic arc-I type field (Fig. 8.13a). In the $\mathrm{Zr}$ versus $\mathrm{TiO}_{2}$ diagram of Syme (1998), they plot in the arc association (Fig. 8.13b). No $\varepsilon N d$ values are yet available for this 
(a)

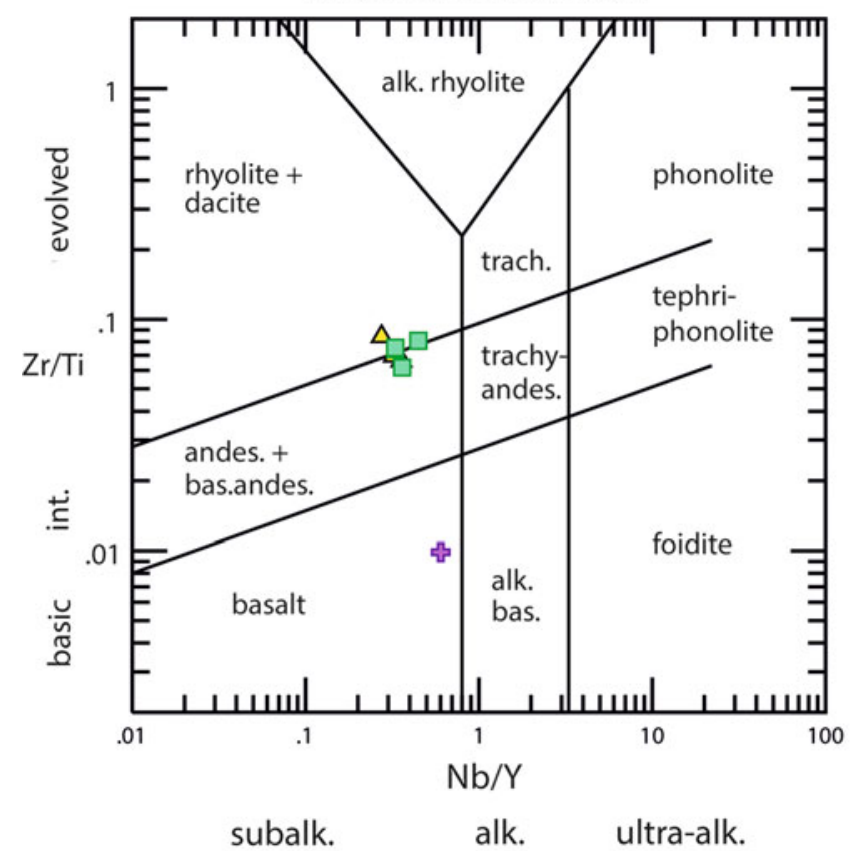

(b) Upper Ordovician

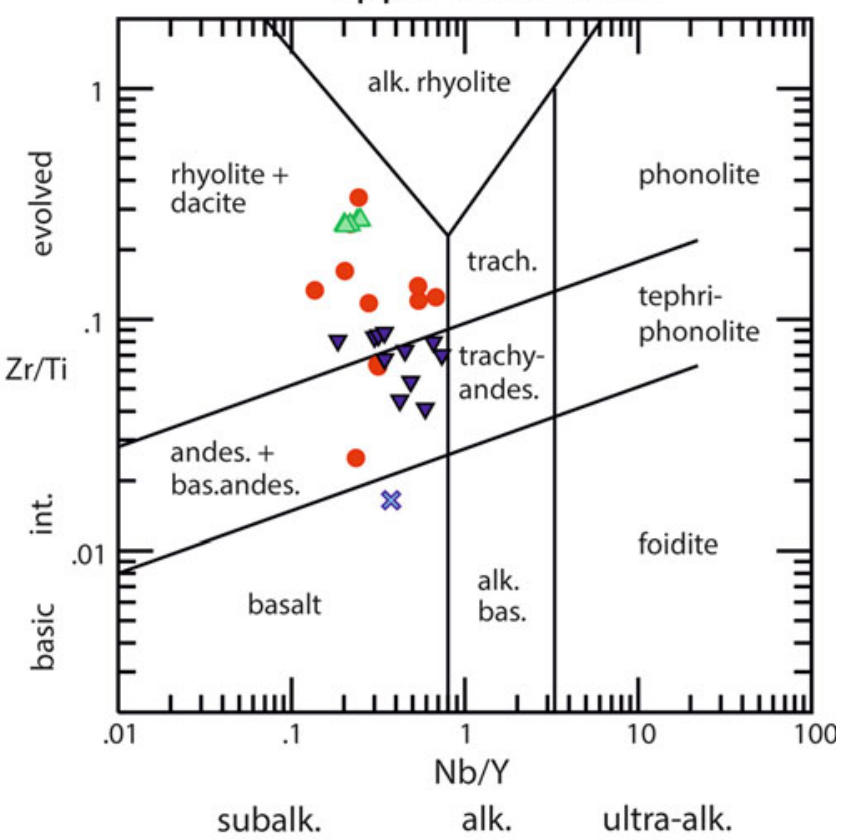

Fig. 8.9 $\mathrm{Zr} / \mathrm{Ti}$ versus $\mathrm{Nb} / \mathrm{Y}$ diagram (Pearce 1996). a Uppermost Lower-Middle Ordovician rocks; b Upper Ordovician rocks (data after Robert and Thiébaut 1976; Calvet et al. 1988; Castiñeiras et al. 2008; Navidad et al. 2010; Liesa et al. 2011; Navidad et al. 2018)

assemblage. All these geochemical data suggest a calc-alkaline magmatic source from active margin environments related to the first stages of extension, as pointed out by Calvet et al. (1988).

The Gneissic Assemblage A includes 4 samples of the Roc de Frausa (Castiñeiras et al. 2008), Albera (Liesa et al. 2011) and Canigó (Navidad et al. 2018) massifs. They show $\mathrm{SiO}_{2}$ contents ranging between 67.17 and $73.62 \%$. They are peraluminous $(\mathrm{A} / \mathrm{CNK}=1.20-1.10)$ and subalkaline, with an average content of $\mathrm{Nb} / \mathrm{Y}=0.37$ (Fig. 8.9a). REE patterns present more fractionated values for LREE $\left(\mathrm{La}_{\mathrm{n}} / \mathrm{Sm}_{\mathrm{n}}=\right.$ 3.13) than for HREE $\left(\mathrm{Gd}_{\mathrm{n}} / \mathrm{Yb}_{\mathrm{n}}=1.43\right)$ being $(\mathrm{La} / \mathrm{Yb})_{\mathrm{n}}=6.52$. The average Eu anomalies show moderate negative values $(0.39)$ reflecting plagioclase crystallization (Fig. 8.10c). In the spider-diagram of Palme and O'Neil (2004), they show negative anomalies of $\mathrm{Nb}$ reflecting crustal magmas, $\mathrm{Sr}$ and $\mathrm{Ti}$ (Fig. 8.10d) suggesting fractionation of plagioclase and $\mathrm{Fe}-\mathrm{Ti}$ oxides, respectively. The overall chondrite-normalized pattern is close to the values of the Upper Continental Crust of Rudnick and Gao (2004), with slight enrichment in the $\mathrm{Th} / \mathrm{Nb}$ (average $=1.13$ ) and $\mathrm{Th} / \mathrm{La}$ (average $=0.56$ ) ratios, and depletion in the $\mathrm{La} / \mathrm{Nb}$ (average $=2.43), \mathrm{Th} / \mathrm{Yb}($ average $=3.50)$ and $\mathrm{Nb} / \mathrm{Yb}($ average $=3.06)$ ratios close to EMORB values ( 3.5 values of Sun and McDonough 1989) (Fig. 8.11b). In the tectonic diagram of Pearce et al. (1984), the samples plot in the volcanic arc-I type field (Fig. 8.13a), whereas in the $\mathrm{Zr}$ versus $\mathrm{TiO}_{2}$ diagram of Syme (1998) they plot in the arc association (Fig. 8.13b). No $\varepsilon N d$ values are available for this assemblage. All the geochemical characters outlined above indicate that they are similar to the above-reported volcanic assemblage, so these rocks were mainly derived from a continental crustal source. Navidad et al. (2010) suggested that crustal recycling would account for the volcanic arc signature of these samples. This signature was probably inherited by melting of a pre-existing Neoproterozoic-Lower Palaeozoic calc-alkaline crust.

\section{(ii) Late Ordovician magmatism}

A Late Ordovician magmatic pulse yielded a varied suite of magmatic rocks. Small granitic bodies are emplaced in the Canaveilles and Jujols strata of the Canigó massif and constitute the protoliths of the Cadí, Casemí and Núria 
Middle and Upper Ordovician Basic rocks
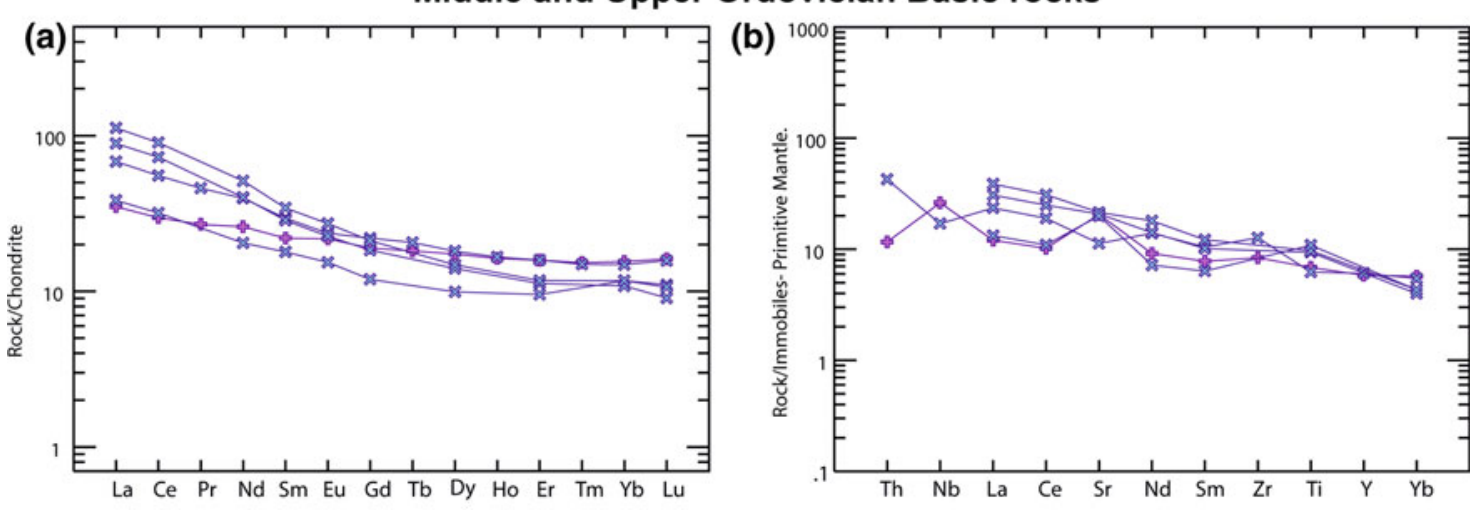

\begin{tabular}{|c|c|c|c|c|c|}
\hline Pyrenees & $(\mathrm{La} / \mathrm{Yb})_{\mathrm{n}}$ & $(\mathrm{La} / \mathrm{Sm})_{\mathrm{n}}$ & $\mathrm{Eu} / \mathrm{Eu}^{*}$ & $(G d / Y b)_{n}$ & \\
\hline Bas - Md O $(n=1)$ & 2.13 & 1.54 & 1.06 & 1.19 & \\
\hline Bas - Up O $(n=5)$ & 6.08 & 2.62 & 0.97 & 1.47 & x Meta \\
\hline
\end{tabular}

\section{Lower- Middle Ordovician Acid \& Intermediate rocks}
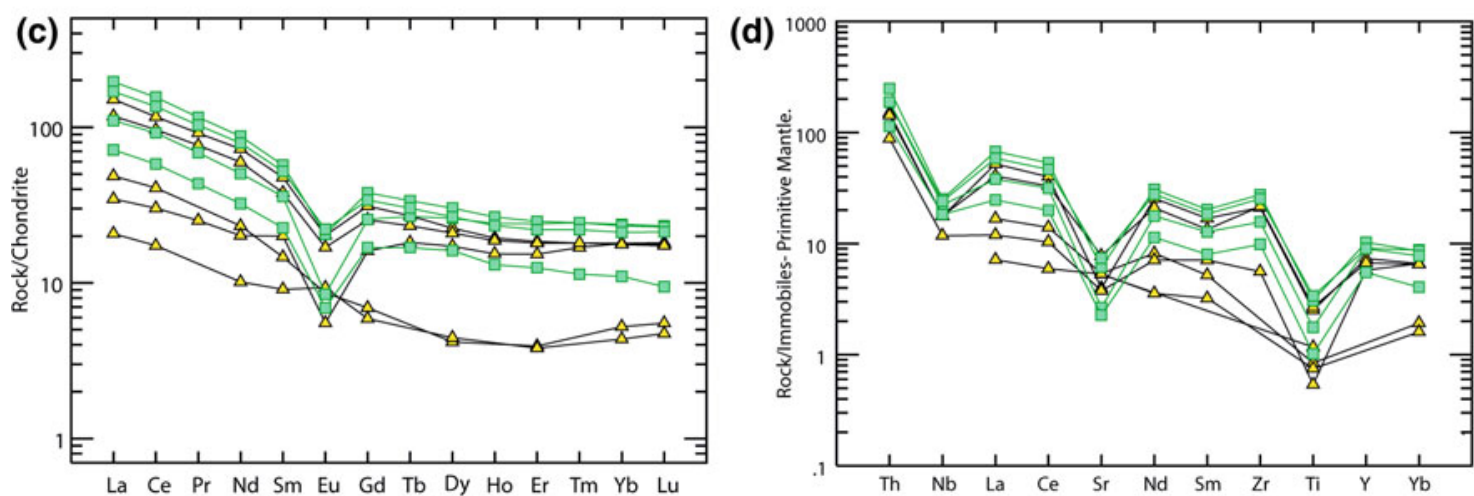

\begin{tabular}{|l|c|c|c|c|}
\hline Pyrenees & $(\mathrm{La} / \mathrm{Yb})_{n}$ & $(\mathrm{La} / \mathrm{Sm}) \mathrm{n}$ & $\mathrm{Eu} / \mathrm{Eu}^{*}$ & $(\mathrm{Gd} / \mathrm{Yb}) \mathrm{n}$ \\
\hline Vol A $(\mathrm{n}=6)$ & 5.88 & 2.63 & 0.68 & 1.32 \\
\hline Gneiss A $(\mathrm{n}=4)$ & 6.52 & 3.13 & 0.39 & 1.43 \\
\hline
\end{tabular}

$\triangle$ Vol A

a Gneiss A

\section{Upper Ordovician Acid \& Intermediate rocks}
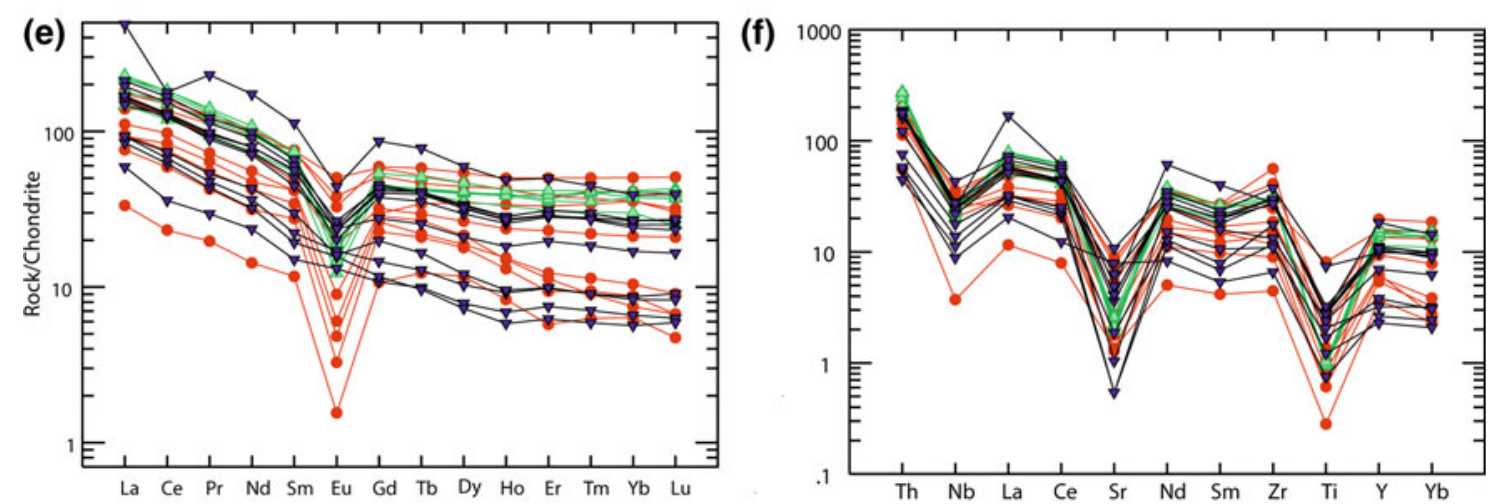

\begin{tabular}{|l|c|c|c|c|}
\hline Pyrenees & $(\mathrm{La} / \mathrm{Yb})_{n}$ & $(\mathrm{La} / \mathrm{Sm})_{n}$ & $\mathrm{Eu} / \mathrm{Eu}^{*}$ & $(\mathrm{Gd} / \mathrm{Yb})_{n}$ \\
\hline Vol B $(\mathrm{n}=14)$ & 8.75 & 3.40 & 0.64 & 1.75 \\
\hline Gneiss B $(\mathrm{n}=11)$ & 6.21 & 2.57 & 0.36 & 1.75 \\
\hline Gneiss C $(\mathrm{n}=5)$ & 5.15 & 2.88 & 0.28 & 1.24 \\
\hline
\end{tabular}

v VolB

- Gneiss B

$\triangle$ Gneiss C

Fig. 8.10 Geochemical features; a chondrite-normalized REE patterns for basic Middle and Upper Ordovician rocks; b spider-diagram for basic Middle and Upper Ordovician rocks; $\mathbf{c}$ chondrite-normalized REE patterns for acid and intermediate Middle Ordovician rocks; d spider-diagram for acid and intermediate Middle Ordovician rocks e chondrite-normalized REE patterns for acid and intermediate Upper Ordovician rocks; $\mathbf{f}$ spider-diagram for acid and intermediate Upper Ordovician rocks. (Chondrite normalizing values of Sun and McDonough 1989 and Primitive Mantle normalizing values of Palme and O’Neil 2004) 
(a) Middle and Upper Ordovician Basic rocks

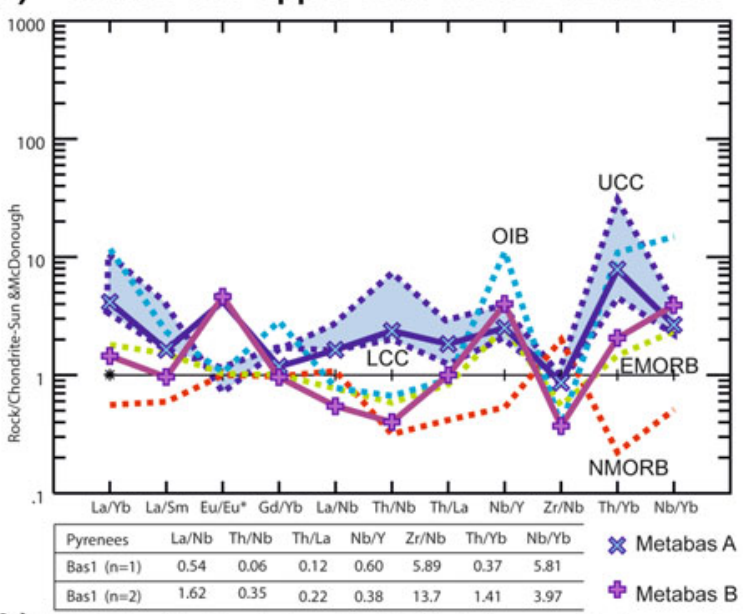

(b) Middle Ordovician Acid \& Intermediate rocks

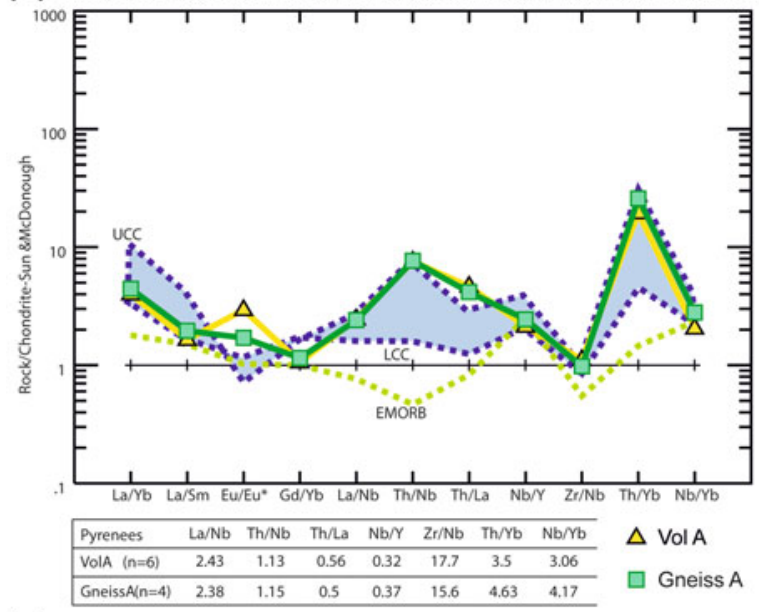

(c) Upper Ordovician Acid \& Intermediate rocks

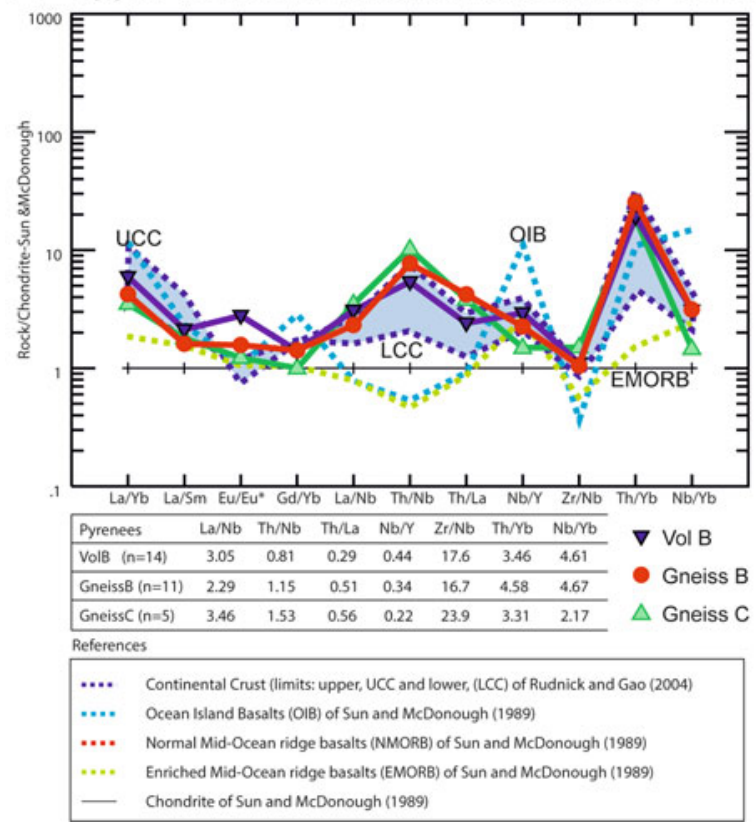

Fig. 8.11 Chondrite-normalized isotope ratios patterns (Sun and McDonough 1989). a mafic Middle and Upper Ordovician rocks; b acid and intermediate Middle Ordovician rocks; c acid and intermediate Upper Ordovician rocks. Blue area: Continental crust values of Rudnick and Gao (2004) gneisses. The Cadí gneiss (Guitard 1970), dated at $456 \pm 5$ Ma by Casas et al. (2010), is an aluminous metagranite body with petrographic characteristics similar to those of the Canigó gneiss; it represents the lowest structural unit recognized in the Canigó massif (Fig. 8.8). The Casemí gneiss (Guitard 1970) is a tabular body up to $1000 \mathrm{~m}$ thick mainly made up of fine-grained biotitic and amphibolic granitic gneisses. Geochronological data indicate a Late Ordovician age for the protolith of this orthogneiss (446 \pm 5 and $452 \pm 5 \mathrm{Ma} \mathrm{Ma}$, SHRIMP U-Pb in zircon, Casas et al. 2010). In the southern Canigó massif, the protoliths of the Núria granitic gneiss and the homonymous augen gneiss (Santanach 1972b) also yield Late Ordovician ages (457 \pm 4 and $457 \pm 5 \mathrm{Ma}$, respectively, Martínez et al. 2011). Moreover, metre-scale thick bodies of metadiorite are interlayered in the micaschists of the Balaig series, which has also yielded a Late Ordovician age for the formation of its protolith (453 $\pm 4 \mathrm{Ma}$, SHRIMP U-Pb in zircon, Casas et al. 2010) (Fig. 8.8).

Coeval calc-alkaline volcanic rocks (ignimbrites, andesites and volcaniclastic rocks) are interbedded in the Upper Ordovician of the Ribes de Freser and Bruguera units. The lower part of the Ribes de Freser unit is made up of dioritic bodies and volcaniclastic rocks, whereas rhyolitic lava flows and ignimbrites predominate in the central part, and ash levels, ignimbrites and volcaniclastic rocks constitute its upper part. The Ribes granophyric body, dated at $458 \pm 3$ Ma by Martínez et al. (2011), crops out at the base of the Upper Ordovician. On the other hand, the rhyolitic ignimbrites and andesitic lavas of the Bruguera unit have been recently dated at ca. 455 Ma by Martí et al. (2014). This volcanism was mainly explosive and displays a calc-alkaline affinity (Martí et al. 1986). Based on their geochemical data, we have differentiated four Upper-Ordovician magmatic assemblages: the metabasites B, the Volcanic Assemblage B and the Gneissic Assemblages $\mathrm{B}$ and $\mathrm{C}$.

The metabasites B include 5 samples of the Marialles diorite (Navidad et al. 2010) and the alkali-pillow basalts of the Pierrefite massif (Calvet et al. 1988). They are undersaturated with $\mathrm{SiO}_{2}$, whose content ranges from 47.3 to 52.4 wt $\%$. Most of them are metaluminous (average A/CNK ratio $=0.98)$, although a sample $(25-1)$ from the Pierrefite massif presents a value of 1.47. In the Pearce's diagram (1996), the assemblage plots in the subalkaline field (Fig. 8.9b), whereas the Pierrefite samples are alkaline in the Shervais (1982) diagram with $\mathrm{Ti} / \mathrm{V}$ values $=100$ to 50 . The REE patterns present more fractionated values for LREE $\left(\mathrm{La}_{\mathrm{n}} / \mathrm{Sm}_{\mathrm{n}}=2.62\right)$ than HREE $\left(\mathrm{Gd}_{\mathrm{n}} / \mathrm{Yb}_{\mathrm{n}}=1.47\right)$, without $\mathrm{Eu}$ anomalies and higher slopes that the Cortalets metabasites (Fig. 8.10e) suggesting little plagioclase fractionation. Most of them show $\mathrm{Nb}, \mathrm{Sr}$ and $\mathrm{Ti}$ negative anomalies in the spider diagram of Palme and O'Neil (2004) (Fig. 8.10b). This 
assemblage displays a different behaviour in the $\mathrm{La} / \mathrm{Nb}$, $\mathrm{Th} / \mathrm{Nb}, \mathrm{Th} / \mathrm{La}, \mathrm{Zr} / \mathrm{Nb}$ (depleted) and $\mathrm{Nb} / \mathrm{Y}$ (enriched) ratios that the Cortalet metabasite. The $\mathrm{Th} / \mathrm{La}, \mathrm{Zr} / \mathrm{Nb}$ and $\mathrm{Th} / \mathrm{Yb}$ values are close to the Ocean Island basalts of Sun and McDonough (1989), while the $\mathrm{Nb} / \mathrm{Y}$ value is close to the Upper Continental Crust of Rudnick and Gao (2004), and the $\mathrm{Th} / \mathrm{Nb}$ ratio is close to the NMORB values of Sun and McDonough (1989) (Fig. 8.11a). In the tectonic discrimination diagram of Wood (1980), this assemblage plots in the Ocean Island Basalts domain (Fig. 8.12a), in the Pearce's (2008) diagram in the MORB array (Fig. 8.12b), and in the $\mathrm{TiO}_{2} / \mathrm{Yb}$ versus $\mathrm{Nb} / \mathrm{Yb}$ diagram (Fig. 8.12c) the dataset shows a distinct E-MORB character. The $\mathrm{Sm}-\mathrm{Nd}$ isotopic data obtained from the Marialles sample are given in Table 8.1 and plotted in Fig. 8.14. The reference age considered for the emplacement of the Marialles diorite is $453 \mathrm{Ma}$ (Navidad et al. 2010). The analysed sample shows a ${ }^{147} \mathrm{Sm} /{ }^{144} \mathrm{Nd}$ ratio of 0.1474 , slightly negative $\varepsilon N d$ values $(-0.8)$ and a TDM age of $1.18 \mathrm{Ga}$. This value could indicate that their protoliths were derived from mantle melts with heterogeneous crustal contamination (Navidad et al. 2010). In summary, the geochemical data discussed above could reflect a more primitive origin mantle-derived but with crustal contamination at their origin.

The Volcanic Assemblage B includes 14 samples from the Els Metges volcanic tuffs, Les Gavarres epiclastic ash (Navidad et al. 2010) and the Ribes de Freser rhyolitic lavas (Robert and Thiébaut 1976). Although no geochemical data are available, we suggest including in this assemblage the Bruguera volcanic rocks due to their similar field characteristics. This assemblage shows a $\mathrm{SiO}_{2}$ content ranging between 86.06 and $62.98 \%$. They are peraluminous $(\mathrm{A} / \mathrm{CNK}=3.63-1.04)$ and subalkaline, with an average content of $\mathrm{Nb} / \mathrm{Y}=0.44$ (Fig. 8.9b). REE patterns present more fractionated values for LREE $\left(\mathrm{La}_{\mathrm{n}} / \mathrm{Sm}_{\mathrm{n}}=3.40\right)$ than HREE $\left(\mathrm{Gd}_{\mathrm{n}} / \mathrm{Yb}_{\mathrm{n}}=1.75\right)$ being $(\mathrm{La} / \mathrm{Yb})_{\mathrm{n}}=8.75$. The average Eu anomalies show negative values (0.64) reflecting plagioclase crystallization (Fig. 8.10e). In the spiderdiagram of Palme and O'Neil (2004), they show negative anomalies of $\mathrm{Nb}, \mathrm{Sr}$ and $\mathrm{Ti}$ (Fig. 8.10f). Overall chondrite-normalized pattern are close to the values of the Upper Continental Crust of Rudnick and Gao (2004), with slight enrichment in the $\mathrm{La} / \mathrm{Nb}$ (average $=3.05$ ) and $\mathrm{Zr} / \mathrm{Nb}$ (average $=17.6$ ) ratios, and depletion in the $\mathrm{Th} / \mathrm{Nb}$ (average $=0.81), \quad \mathrm{Th} / \mathrm{La} \quad$ (average $=0.29), \quad \mathrm{Nb} / \mathrm{Y} \quad$ (average $=$ $0.44), \mathrm{Th} / \mathrm{Yb}$ (average $=3.46$ ) and $\mathrm{Nb} / \mathrm{Yb}$ (average $=4.61$ ) ratios (Fig. 8.11c). In the tectonic diagram of Pearce et al. (1984), most of samples plot in the volcanic arc-I type field and the anomalous rift field (Fig. 8.13c). In the $\mathrm{Zr}$ versus $\mathrm{TiO}_{2}$ diagram of Syme (1998), most of samples plot in the arc association (Fig. 8.13d). The volcanic tuffs of Les Gavarres show an ${ }^{147} \mathrm{Sm} /{ }^{144} \mathrm{Nd}$ isotope ratio ranging between 0.1410 and 0.1372 and $\varepsilon N d$ between -5.1 and -4.8, indicating a crustal origin (Navidad et al. 2010). Similar isotopic values have been obtained by Martínez et al. (2011) for the Ribes granophyre $(\varepsilon N d-2.6)$ indicating also a crustal origin.

The Gneissic Assemblage B includes 11 samples from the Canigó and Cadí gneisses, (Canigó massif, Navidad et al. 2010; Navidad et al. 2018). Although no geochemical data are available, we suggest including here the Núria gneisses. The assemblage shows a $\mathrm{SiO}_{2}$ content between 76.42 and $56.47 \%$. The samples are peraluminous $(\mathrm{A} / \mathrm{CNK}=1.24-0.64)$ and subalkaline, with an average content of $\mathrm{Nb} / \mathrm{Y}=0.34$ (Fig. 8.9b). REE patterns present more fractionated values for $\operatorname{LREE}\left(\mathrm{La}_{\mathrm{n}} / \mathrm{Sm}_{\mathrm{n}}=3.13\right)$ than $\operatorname{HREE}\left(\mathrm{Gd}_{\mathrm{n}} / \mathrm{Yb}_{\mathrm{n}}=1.43\right)$ being $(\mathrm{La} / \mathrm{Yb})_{\mathrm{n}}=6.38$. The average Eu anomalies show moderate negative values $(0.36)$ reflecting plagioclase crystallization (Fig. 8.10e). In this assemblage, two subsets can be distinguished, one with flat slope and another with negative slope. This could indicate two different magmatic sources. In the spider-diagram of Palme and O'Neil (2004), they show negative anomalies of $\mathrm{Nb}, \mathrm{Sr}$ and $\mathrm{Ti}$ (Fig. 8.10f). The overall chondrite-normalized pattern is close to the values of the Upper Continental Crust of Rudnick and Gao (2004), with a slight enrichment in the $\mathrm{Th} / \mathrm{Nb}$ (average $=1.15)$, Th/La (average $=0.51)$ and $\mathrm{Zr} / \mathrm{Nb}$ (average $=16.7)$ ratios and depletion in the $\mathrm{La} / \mathrm{Nb}$ (average $=2.29$ ) and $\mathrm{Th} / \mathrm{Yb}$ (average $=4.58)$ values. The $\mathrm{Nb} / \mathrm{Y}$ (average $=0.34)$ value is close to the Lower Continental Crust of Rudnick and Gao (2004) (Fig. 8.11c). In the tectonic diagram of Pearce et al. (1984), the samples plot in the volcanic arc-I type field and the anomalous rift field (Fig. 8.13c). In the $\mathrm{Zr}$ versus $\mathrm{TiO}_{2}$ diagram of Syme (1998), the samples plot both in the arc association (Fig. 8.13d) and the extensional field. The Cadí orthogneisses show a $\mathrm{Nd}$ isotope ratio (0.5118) similar to the most differentiated assemblage (Casemí, Gneissic Assemblage $\mathrm{C}$; see below) and a higher negative isotopic signature with $\varepsilon N d$ negative values ( -4.2 to -5.2 ) (Fig. 8.14) than these gneisses (Gneissic Assemblage C) suggesting a crustal origin (Navidad et al. 2010). Similar isotopic values have been obtained by Martínez et al. (2011) for the Núria gneisses ( $\varepsilon N d$ between -3.0 and -4.7 ). All the geochemical characters outlined above indicate that this assemblage was mainly derived from different magmas of continental crustal source.

The Gneissic Assemblage $\mathrm{C}$ includes 5 samples from the Casemí and Canigó gneisses (Canigó massif, Navidad et al. 2010). They present more silica and alkalis and less $\mathrm{Al}, \mathrm{Fe}$ and $\mathrm{Mg}$ than the Gnesissic Assemblage B. They show a narrow range of composition $\left(73.62 \%<\mathrm{SiO}_{2}<75.02 \%\right)$ and are peraluminous $(\mathrm{A} / \mathrm{CNK}=1.24-0.64)$ and subalkaline, with an average content of $\mathrm{Nb} / \mathrm{Y}=0.22$ (Fig. 8.9b). The REE pattern is similar to the subset with flat slope of HREE in the Gneissic Assemblage B, with more fractionated 


\section{Lower-Middle and Upper Ordovician Basic rocks}

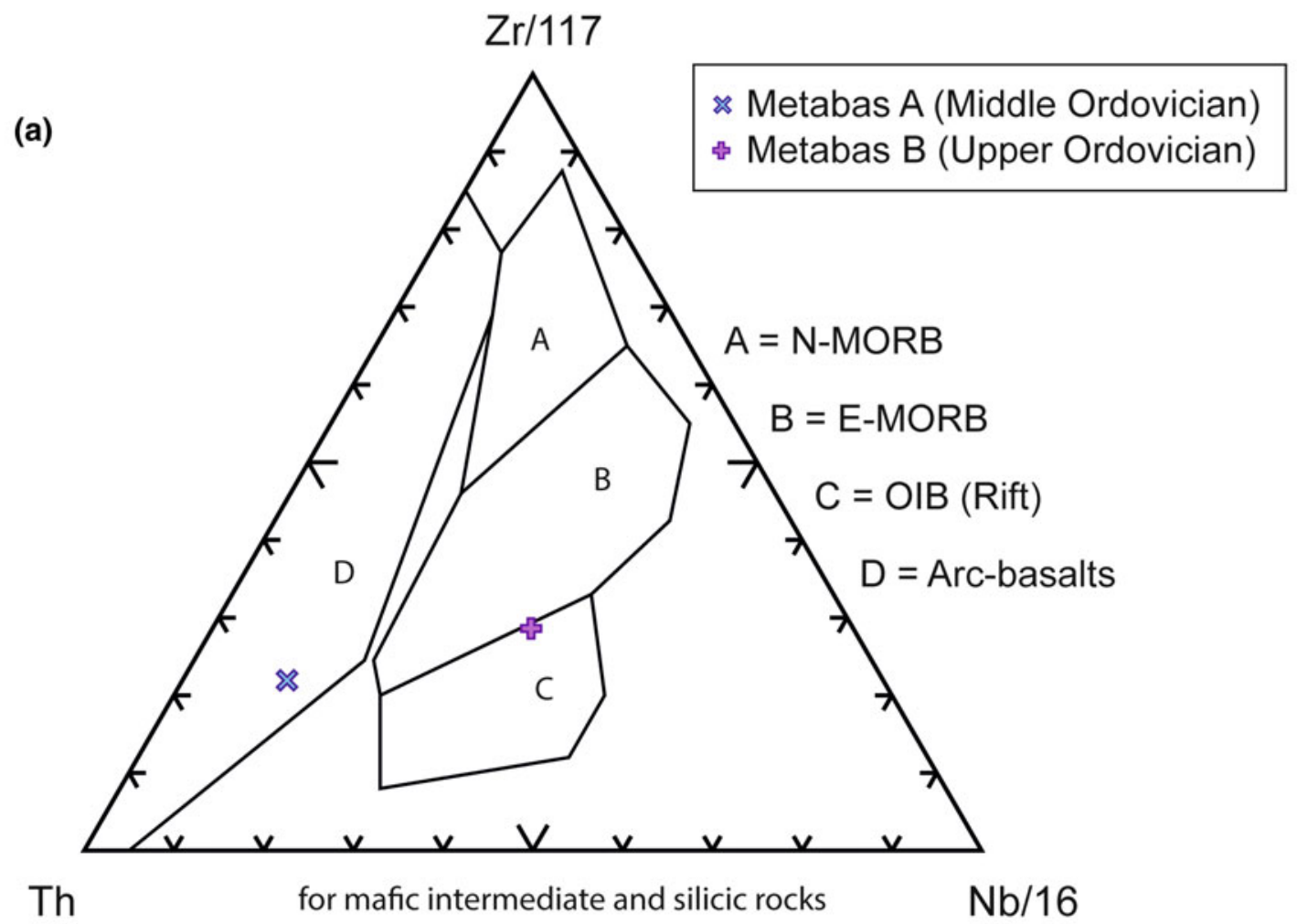

(b)

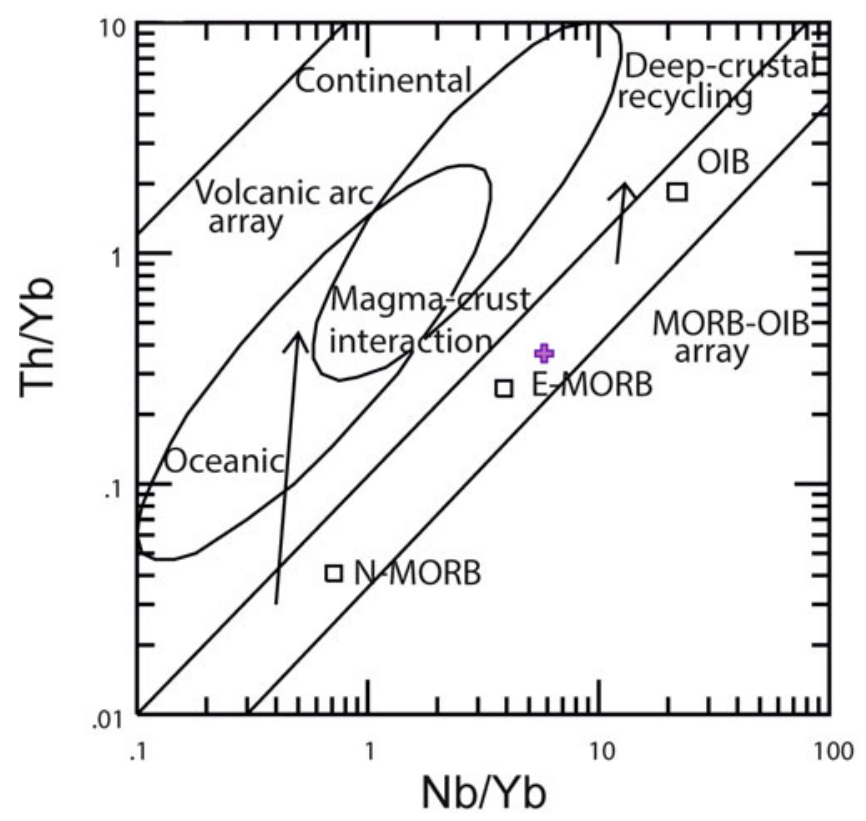

(c)

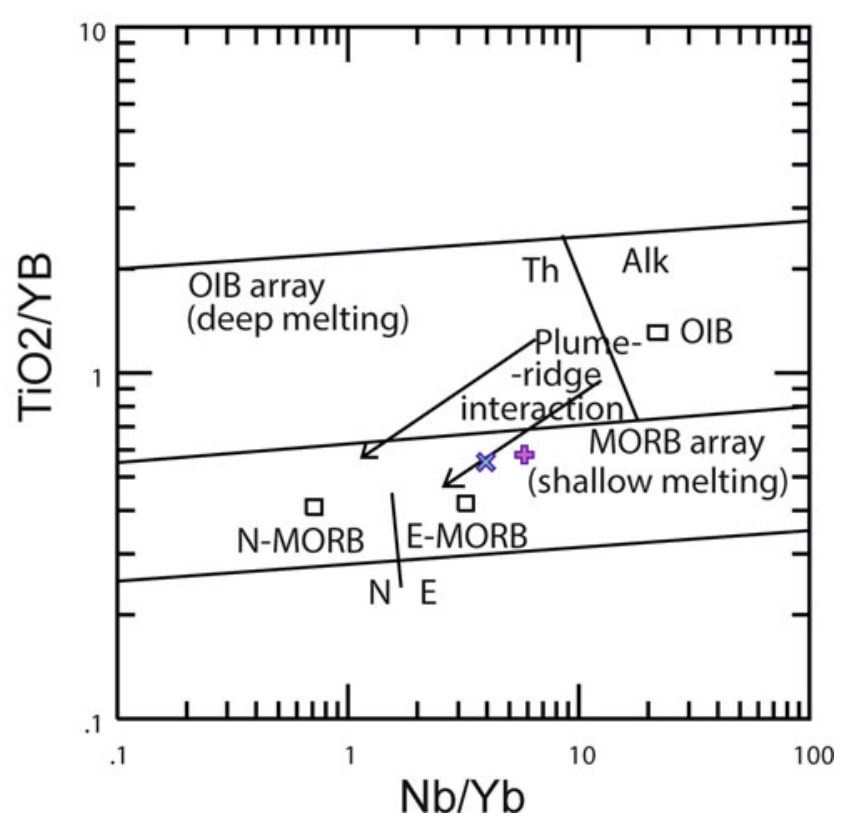

Fig. 8.12 Tectonic discriminating diagram of basic rocks. a Wood (1980); b Th/Yb versus Nb/Yb of Pearce (2008); $\mathbf{c} \mathrm{TiO} / 2 / \mathrm{Yb}$ versus Nb/Yb of Pearce (2008) 


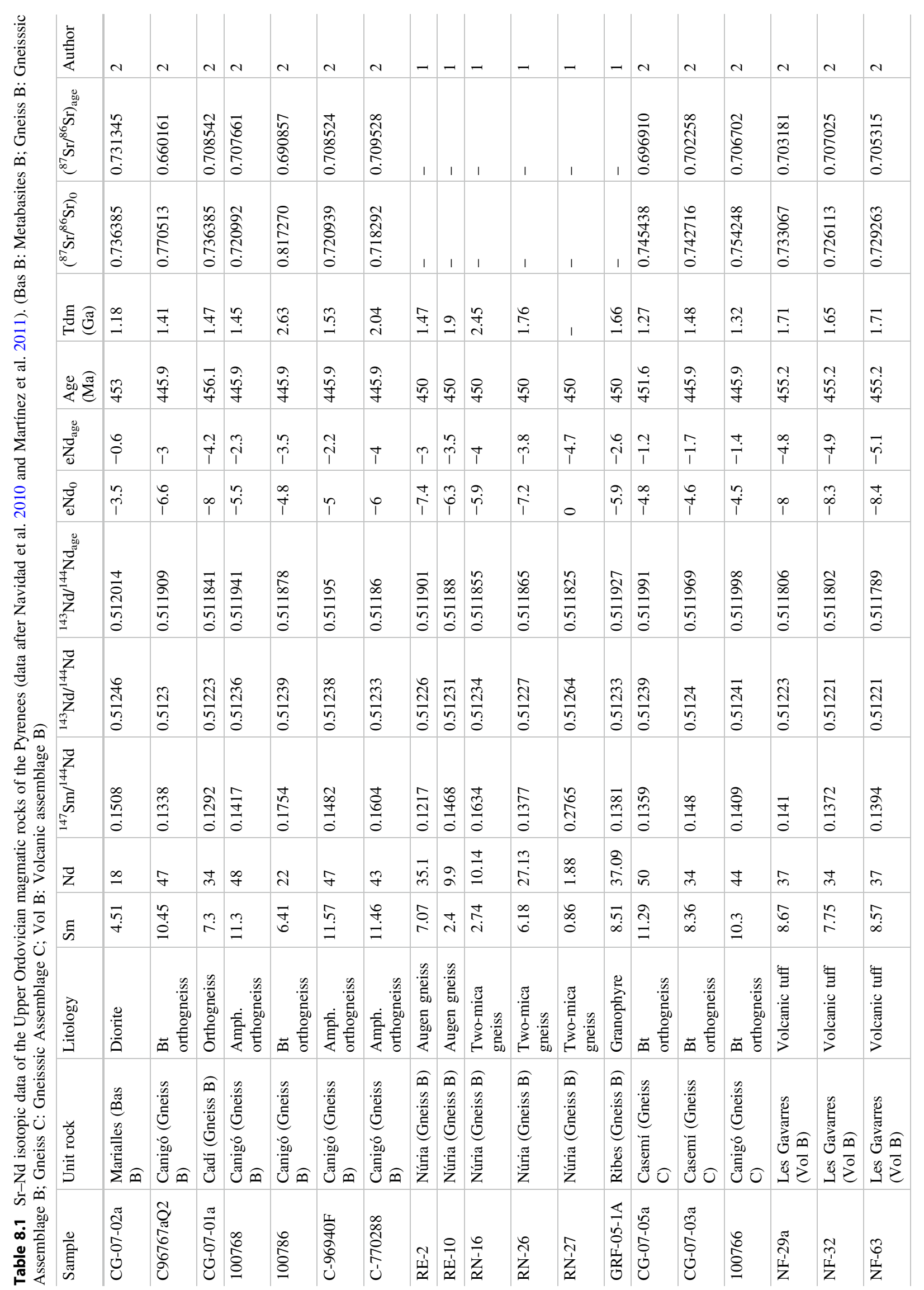




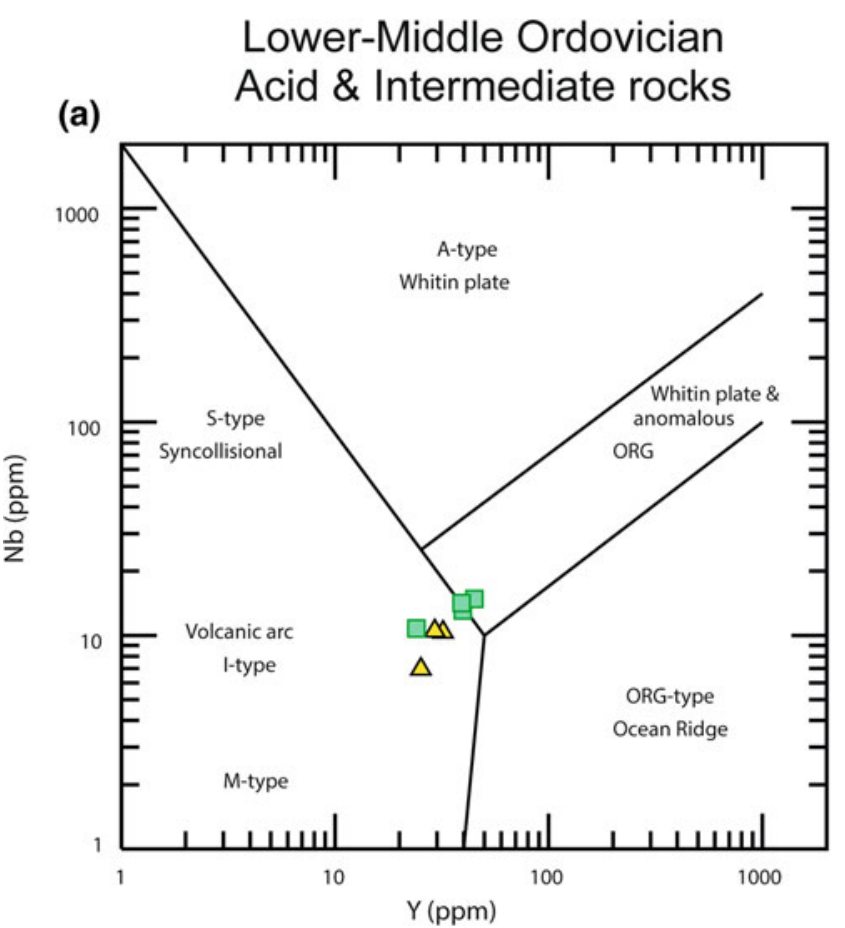

$\triangle$ Vol A $\square$ Gneiss A

(b)

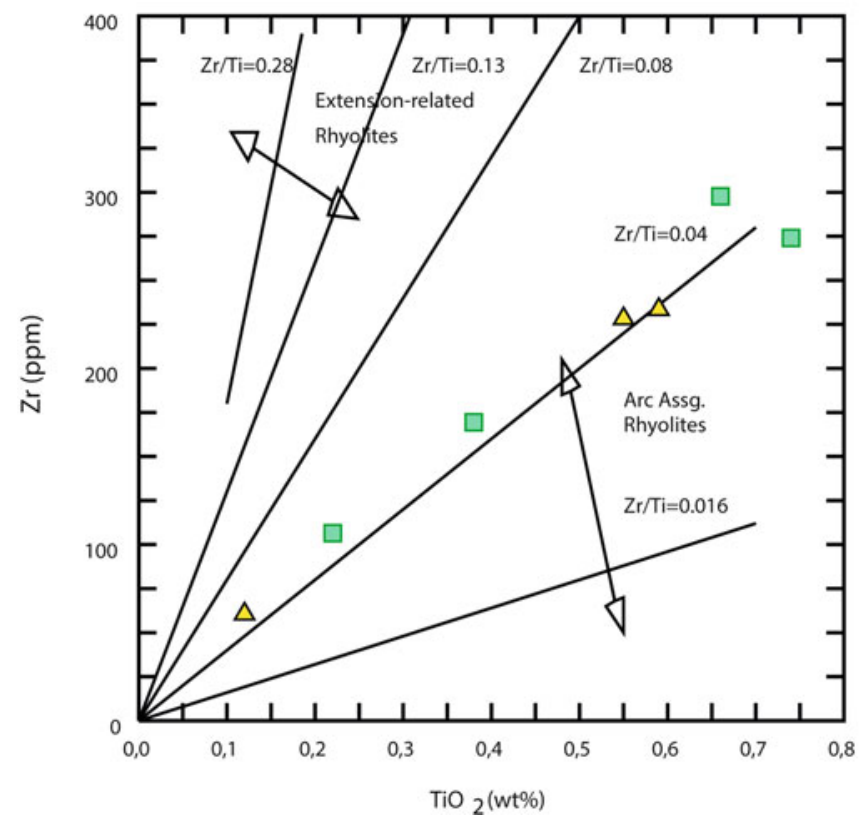

Upper Ordovician Acid \& Intermediate rocks

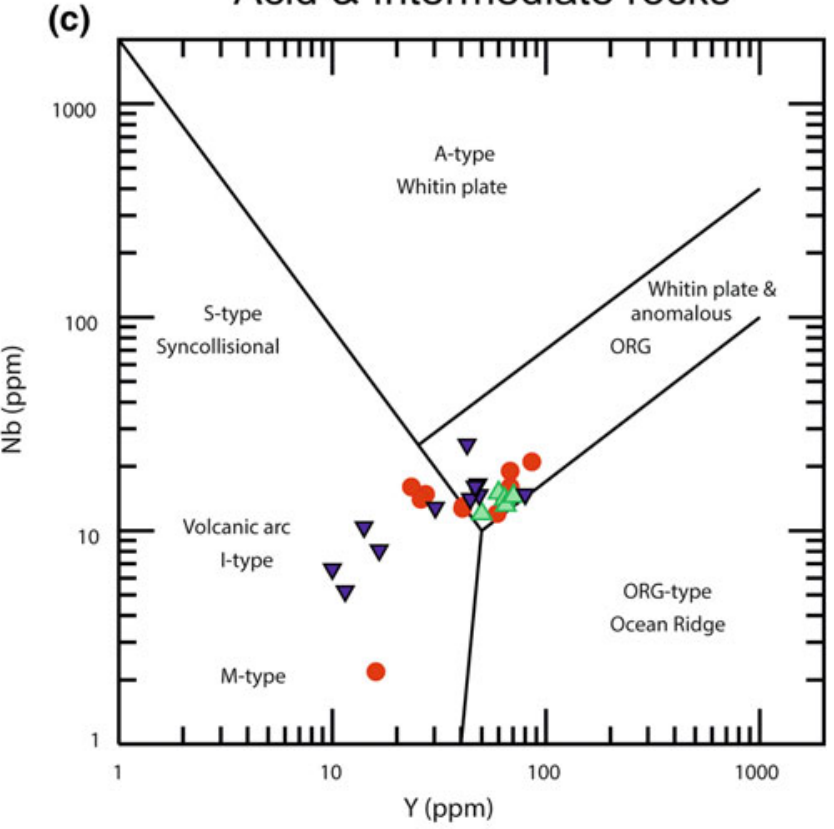

Vol B Gneiss B $\triangle$ Gneiss C

(d)

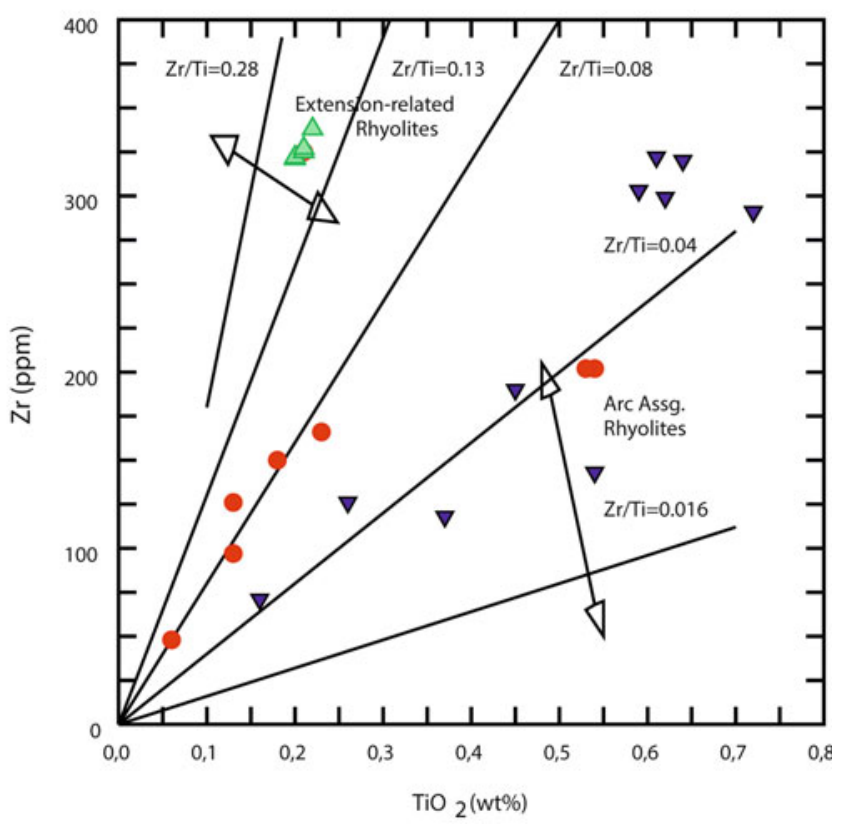

Fig. 8.13 Tectonic discriminating diagram of acid and intermediate rocks. a and $\mathbf{c} \mathrm{Y}$ versus Nb diagram (Pearce et al. 1984); b and $\mathbf{d} \mathrm{Zr}$ versus $\mathrm{TiO}_{2}$ diagram (Syme 1998)

values for $\operatorname{LREE}\left(\mathrm{La}_{\mathrm{n}} / \mathrm{Sm}_{\mathrm{n}}=3.13\right)$ than HREE $\left(\mathrm{Gd}_{\mathrm{n}} /\right.$ $\left.\mathrm{Yb}_{\mathrm{n}}=1.43\right)$, being $(\mathrm{La} / \mathrm{Yb})_{\mathrm{n}}=6.38$. The average $\mathrm{Eu}$ anomalies show moderate negative values (0.36) reflecting plagioclase crystallization (Fig. 8.10e). In the spiderdiagram of Palme and O'Neil (2004), they show negative anomalies of $\mathrm{Nb}, \mathrm{Sr}$ and $\mathrm{Ti}$ (Fig. 8.10f). Overall chondritenormalized pattern close to the values of the Upper Continental Crust of Rudnick and Gao (2004) values with slight enrichment in the $\mathrm{Th} / \mathrm{Nb}$ (average $=1.15$ ), $\mathrm{Th} / \mathrm{La}$ (average $=0.51)$ and $\mathrm{Zr} / \mathrm{Nb}$ (average $=16.7)$ and depletion in the 


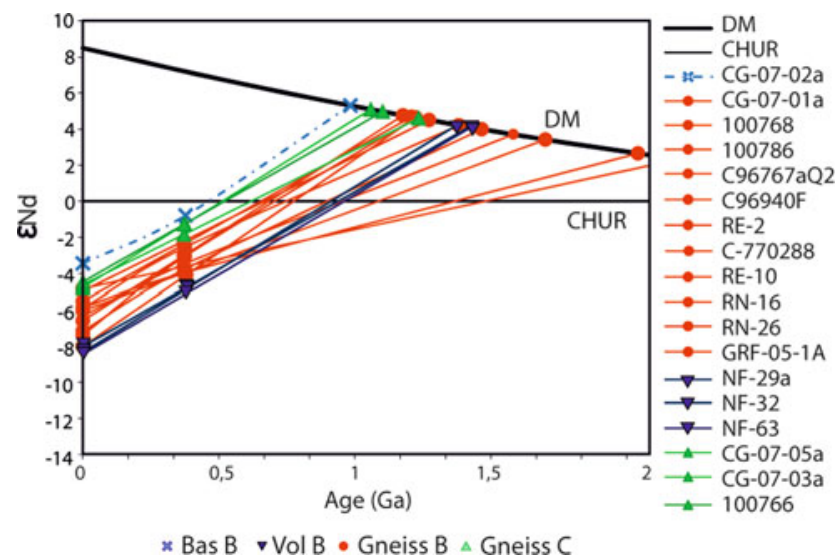

Fig. 8.14 $\varepsilon N d$ versus age diagram (DePaolo and Wasserburg 1976; DePaolo 1981) for the Upper Ordovician magmatic rocks of the Pyrenees (data after Navidad et al. 2010; Martínez et al. 2011). Depleted mantle evolution calculated according to DePaolo (1981)

$\mathrm{La} / \mathrm{Nb}$ (average $=2.29)$ and $\mathrm{Th} / \mathrm{Yb}$ (average $=4.58$ ) ratios. $\mathrm{The} \mathrm{Nb} / \mathrm{Y}$ (average $=0.34$ ) value is close to the Lower Continental Crust of Rudnick and Gao (2004) (Fig. 8.11c). This suggests a certain degree of crustal contamination and recycling of materials. In the tectonic diagram of Pearce et al. (1984), the samples plot in the volcanic arc-I type field and the anomalous rift (Fig. 8.13c). In the $\mathrm{Zr}$ versus $\mathrm{TiO}_{2}$ diagram of Syme (1998), the data plot in the extensional field (Fig. 8.13d). The initial Nd isotope ratio of the Casemí gneiss $\left({ }^{147} \mathrm{Sm} /{ }^{144} \mathrm{Nd}\right.$ between 0.1480 and 0.1359 and $\varepsilon \mathrm{Nd}$ between -1.9 and -1.3 ) indicates that their protoliths were derived from mantle melts with heterogeneous crustal contamination (Navidad et al. 2010). Castiñeiras et al. (2011) reached similar conclusions on the basis of zircon composition. Despite their different age, the zircons from the Cadí orthogneiss and the Albera gneiss exhibit similar characteristics. The zircon composition suggests that this mineral grew in a melt formed by anatexis of continental crust. In contrast, zircons from the Casemí gneiss and the metadiorite point out that the mantle was involved in the origin of these rocks. Extrapolations of $\varepsilon \mathrm{Nd}$ data back to the depleted mantle curve yield TDM values varying between 1.3 and 1.5 Ga (Navidad et al. 2010; Martínez et al. 2011; Fig. 8.14, Table 8.1). The absence of inherited zircons from these ages led the authors to interpret these values as the result of the melting of a Neoproterozoic source mixed with Palaeoproterozoic components.

All geochemical characteristics broadly suggest crustal sources in their parental magmas. According to Navidad et al. (2010), the whole-rock geochemistry shows that the Upper Ordovician orthogneiss of the Canigó massif are compositionally uniform. As fractionation processes cannot be recognized, crustal contamination of mantle melts is the most probable process accounting for the formation of the various geochemical datasets (Casemí biotite and amphibole orthogneisses, and metadiorite).

It should be noted that the latest Early-Mid Ordovician magmatism is coincident with the pre-Late Ordovician episode of uplift and erosion that led to the formation of the Sardic unconformity. Uplift was followed by an extensional pulse that developed normal faults, directly affecting the onset of the basal unconformity and controlling deposition of the (post-Sardic) Upper Ordovician strata and coeval Late Ordovician magmatic activity.

Early and Late Ordovician ages have also been obtained in magmatic bodies from the French Massif Central, such as in the Axial Zone of the Montagne Noire (Somail orthogneiss: $471 \pm 4 \mathrm{Ma}$, Cocherie et al. 2005; Pont de Larn and Gorges d'Heric orthogneisses: $456 \pm 3 \mathrm{Ma}$ and $450 \pm 6 \mathrm{Ma}$, Roger et al. 2004; Saint Eutrope gneiss: $455 \pm 2 \mathrm{Ma}$, Pitra et al. 2012). As in the Pyrenees, the emplacement of Late Ordovician felsic granitic bodies is coeval in the Montagne Noire with a tholeiitic volcanic activity originated by melting of mantle and crustal lithosphere and infilling of rifting branches preserved on the southern Montagne Noire (Álvaro et al. 2016). These authors also describe a similar Late Ordovician volcanism in the Mouthoumet massif and relate it to the end of the Sardic Phase and the opening of rift branches linked to those developed on the southern Montagne Noire.

\subsection{Correlation with Surrounding Areas and Other Northern Gondwanan Domains}

\section{J. J. Álvaro, J. M. Casas, S. Clausen, M. Padel, C. Puddu}

To the west of the Canigó massif, the Jujols Group extends as far as the Noguera Pallaresa and Ribagorçana rivers, where the Serdinya Formation may be correlated with the Seo Formation defined by Hartevelt (1970) in the Orri Dome. In the La Pallaresa dome, the La Massana antiform and the western slopes of the Aston and Hospitalet domes, a siliciclastic-dominated succession, more than $4000 \mathrm{~m}$ thick, was subdivided into three formations by Laumonier et al. (1996), from bottom to top: the Alós d'Isil, Lleret-Bayau and Alins formations. The Alós d'Isil and Alins formations are dominated by shales, locally alternating with thin- to medium-grained sandstones, and are separated by the metasandstones and marbles of the Lleret-Bayau Formation. Despite the lack of any geochronologic or biostratigraphic control, we suggest that the Pallaressa succession should be correlated with the Jujols Group, being the Alós d'Isil, Lleret-Bayau and Alins triad equivalent to the Err, Valcebollère and Serdinya formations, respectively (Fig. 8.9). In the same way, the Jujols Group may be correlated with 
the pre-Sardic rocks of the Garona Dome, which have been subdivided into three terms by García-Sansegundo and Alonso (1989), from bottom to top: the Urets beds, the Bantaillou limestone and the Orlà beds. Again, these terms may be equivalent to the Err, Valcebollère and Serdinya formations, respectively.

In contrast, the Jujols Group cannot be easily recognized in the easternmost Cap de Creus, where some geochronological ages of Cadomian magmatic rocks constrain the depositional ages of the pre-Sardic succession from ca. 570 to $542 \mathrm{Ma}$. In the Albera massif, alternating layers of metapelites and metapsamites form the uppermost part of a metasedimentary succession that is crosscut by a network of acidic subvolcanic porphyritic dykes, which constrain its minimum depositional age to 465-472 Ma (Liesa et al. 2011). This uppermost part can be tentatively correlated with the Jujols Group, although coarse-grained terms (sandstone and conglomerate) are locally abundant in the Albera massif.

The only Cambrian shelly fossils reported until present in the Pyrenees occur in an Alpine thrust sheet of the Terrades area. Abad (1988) described the presence of archaeocyathan patch reefs, alternating with green to brownish shales in an up to $50 \mathrm{~m}$ thick succession, and assigned the sponges to the Cambrian Age 3. A complete taxonomic study by Perejón et al. (1994) confirmed a late Cambrian Age 3. The detailed preservation of pristine microfacies and microbial textures in these limestone strata, contrasting with the traditional marble aspect of any carbonate bed of Cambrian age, is in accordance with the allochthonous provenance of this Alpine thrust slice: the Cambrian limestones of the Salut slice thrust Eocene strata and are, in turn, unconformably overlain by Eocene strata (Pujadas et al. 1989). Biogeographic affinities of the archaeocyaths point to strong similarities with similar assemblages from SW Sardinia (Matoppa Formation of the Nebida Group) (Perejón et al. 1994). A pre-Alpine northward setting, in a lateral prolongation of the archaeocyathbearing carbonates cropping now in SW Sardinia and southern Montagne Noire, may be envisaged.

Since the pioneer work of Cavet (1957), the Ediacaran-Lower Ordovician succession of the Pyrenees has been traditionally compared to fossiliferous successions from the neighbouring southern Montagne Noire. These lithostratigraphic correlations between both Variscan massifs have remained, up to recently, the main way to interpolate the age of the Canaveilles and Jujols groups (Cavet 1957; Laumonier et al. 1996, 2004). The stratigraphic framework of the Montagne Noire has recently been updated (Álvaro et al. 1998, 2014) and better constrained based on recent chronostratigraphic (Devaere et al. 2013, 2014) and geochronologic studies (Roger et al. 2004; Pitra et al. 2012; Padel et al. 2017). As a result, the Valcebollère Formation and, as suggested above, the Lleret Bayau Formation and the Bentaillou limestone from the Central Pyrenees, can be confidently considered as representative of the characteristic Cambrian Age 3-4 episode of subtropical carbonate production highlighted by the Pardailhan and Lastours formations in the Montagne Noire (Álvaro et al. 2010; Devaere et al. 2014) (Fig. 8.2). The upper part of the Valcebollère Formation (limestone/shale alternations and monotonous shales bearing carbonate centimetre-thick nodules) is lithologically equivalent to the La Tanque-Coulouma transition. A distinct lithological difference between the Eastern Pyrenees and the Montagne Noire is marked by the absence, in the former, of the Guzhangian (regional Languedocian) regression represented by the onset of the Ferrals Formation (Álvaro et al. 2007). This sandstone-dominated formation, representative of prograding shoal complexes, is absent in the Eastern Pyrenees (Fig. 8.2). The regression recorded by the input of sandstones marking the uppermost part of the Serdinya Formation (Font Frède Member) may represent the onset of the early Tremadocian regression marked, in the Montagne Noire, by the La Dentelle Formation.

In SW Sardinia, the 1500-3000 m thick Cambrian-Lower Ordovician succession is subdivided into the Nebida, Gonnesa and Iglesias groups (Pillola 1990). The lower siliciclastic deposits of the Sa Tuvara Member (Matoppa Formation, Nebida Group) should represent a lateral equivalent of the Err (Eastern Pyrenees) and Marcory (Montagne Noire) formations (Fig. 8.2). The upper carbonate and siltstone alternations of the Matoppa Formation have yielded a Cambrian Age 3-4 fauna (Pillola 1990) which was correlated with the Pardailhan Formation of Montagne Noire (Álvaro et al. 2010). The Matoppa Formation is conformably overlain by the Punta Manna Formation, the uppermost heterolithic unit of the Nebida Group. The following Gonnesa Group, mainly composed of massive archaeocyathanbearing carbonates, is correlatable with the Pardailhan and Lastours formations (Álvaro et al. 2010). The upper part of the Matoppa Formation, the Punta Manna Formation and the Gonnesa Group were deposited during the Cambrian Epoch 2 and are interpreted as lateral equivalents of the Valcebollère Formation and the La Salut thrust slice (Fig. 8.2). The carbonate sequence of the Gonnesa Group is overlain by the Iglesias Group, which begins with the carbonate-shale alternations and/or nodular limestones of the Campo Pisano Formation that can be considered as a lateral equivalent of the Coulouma Formation (Álvaro et al. 2010) and the upper part of the Valcebollère Formation. The Campo Pisano Formation (Cambrian Series 2-3 transition; Pillola 1990) is conformably overlain by the terrigenous rocks of the Cambrian Series 3-Lower Ordovician Cabitza Formation, correlated herein with the Serdinya Formation.

In SW Sardinia, according to Loi et al. (1995), a regressive trend culminating with local coarse-grained sandstones, is recognized in the middle member of the Cabitza Formation (sensu Gandin and Pillola 1985; Pillola 
1989), biostratigraphically represented by the so-called CAB-4 fossil assemblage, correlatable with the late Languedocian. This sandy-dominant level might represent the Ferrals regression, but somewhat delayed in time. The Acerocare Regressive Event is proposed close to the Cambrian-Ordovician boundary, which lies at the so-called Cabitza "tubi" part and is directly overlain by the first occurrence of Tremadocian graptolites (CAB-6; Loi et al. 1995). Therefore, the lack of the Guzhangian Ferrals Formation regression in the Eastern Pyrennes, present in the Iberian Peninsula, the Montagne Noire and somewhat diachronous in SW Sardinia, might be related to peneplanation of source areas, unable to yield coarse-grained sediments.

The Sardic unconformity recognized in Sardinia and the Pyrenees could be considered as a correlation element for both areas. Such as the Sardic unconformity, the Upper Ordovician successions that follow this unconformity are broadly comparable. In Sardinia, two post-Sardic sequences have been recognized, reported at the SW and SE of the island. The SW Sardinian sequence starts with a conglomerate-to-sandstone, fining-upward package, followed by a sandy-siltstone succession characterized by two late Katian key-levels: the fossiliferous Portixeddu Formation and the carbonate-dominated Domusnovas Formation. The SE Sardinian sequence starts with conglomeratic deposits and volcanic products of Mid Ordovician age, topped by a terrigenous and volcanoclastic complex characterized by a fossiliferous lower Katian level (Punta Serpeddì Formation), and an upper-Katian key carbonate level, the Tuviois Formation (Fig. 8.2). Based on their lithology, fossil record and age, the SW Sardinian sequence is comparable to the Hartevelt's (1970) sequence of the Eastern Pyrenees, where the Rabassa Conglomerate Formation is the corresponding of the Monte Argentu Formation (Sandbian), the Cava Formation (Katian) represents the Monte Orri (Early Katian) and Portixeddu formations (Late Katian), while the Estana Formation (Late Katian) is the lateral equivalent of the Domusnovas Formation (Late Katian). The Ansovell and Bar formations broadly represent the Rio San Marco counterpart (Hirnantian).

The SE Sardinian sequence could be comparable to that cropping out in the Ribes de Freser area. In the Bruguera unit, the Upper Ordovician volcanites that overlie the Sardic unconformity are similar to the volcanic products that overlie the Sardic unconformity in the SE Sardinian sequence. The basal tuffs of the Ribes de Freser unit may correspond to the volcanites of SE Sardinia that overlie the Sardic unconformity, while the Katian sediments that cover the former tuffs represent the Punta Serpeddi Formation (lower Katian) followed by limestones comparable to the Tuviois Formation. The thickness, facies and fossil record of the limestones in the El Baell unit are different from the two above-reported Sardinian sequences. These limestones could be comparable only in age with the Estana Formation (Eastern Pyrenees), the Domusnovas Formation (SW Sardinia) or the Tuviois Formation (SE Sardinia) (Fig. 8.2).

The south-north, proximal-distal palaeogeographic trend recorded in the Lower Palaeozoic of the eastern Pyrenees is repeated across the Mouthoumet and Axial Zone-southern-northern (proximal-to-distal) Montagne Noire transect. Moreover, the biogeographic affinity displayed by the archaeocyaths of the Alpine Salut thrust sheet, and the comparative analysis of zircon provenance (Padel 2016) point to closer palaeogeographic affinities between the Pyrenees and Sardinia than between the Pyrenees and the Montagne Noire. As a result, in addition to the estimated $150-160 \mathrm{~km}$ accumulated in a south-north Alpine displacement of the Pyrenean thrust sheets, other pre-Alpine movements may be envisaged to solve the present-day relationship between the Pyrenees and the Occitan Domain (sensu Álvaro et al. 2016). Dextral shearing along the southern branch of the South Armorican Shear Zone, between 315 and 305 Ma (Martínez Catalán 2012 and references therein), may account for an original westernmost position of the Montagne Noire and the French Central Massif in pre-Variscan, Early Palaeozoic times.

The inner peri-Gondwanan massifs that form the eastern branch of the Variscan Ibero-Armorican Arc (Southern Armorican, Pyrenean and Occitan Domains and lateral prolongation into Corsica and Sardinia) offer a common geodynamic framework during Early Palaeozoic times. They differ from the Iberian Massif (western branch of the same arc) by the absence of Cadomian deformation, the record of Cadomian felsic-dominated volcanic activity crossing the Ediacaran-Cambrian boundary interval, a significant episode of carbonate productivity capping the top of palaeohorsts and volcanosedimentary edifices during Terreneuvian times, the lack of the Toledanian phase (marking the rift/drift transition in parts of the Iberian Peninsula) and the common record of the Sardic phase. The latter is characterized by intrusion of granites in the Pyrenees and the Axial Zone of the Montagne Noire, contemporaneously with the opening of Katian rifting branches and the record of a basaltic-dominated, tholeiitic magmatism in the Mouthoumet and Cabrières klippes (southern Montagne Noire). The palaeorelief generated as a result of the Sardic uplift was succeeded by extensional pulses, tilting, discontinuous erosion of the pre-Sardic basement, and infill of the new palaeorelief with alluvial-to-fluvial deposits, volcanosedimentary complexes and final sealing of the whole palaeotopography during Silurian to Early Devonian times.

The interpretation of the Sardic phase as (i) the onset of a Mid Ordovician arc that developed in North Gondwana as a consequence of subduction of oceanic crust under continental crust (Andean-type convergence; see Di Pisa et al. 1992; Carmignani et al. 2001; Stampfli et al. 2002; Buzzi et al. 2007; 
Funedda and Oggiano 2009), (ii) a change from symmetric to asymmetric opening conditions of the Rheic Ocean leading to local crustal fusion, or (iii) the onset of a rift/drift unconformity similar to the Toledanian one recorded in the Iberian massif, is still open to future discussion.

\subsection{Silurian, Devonian and pre-Variscan Carboniferous}

\section{J. Sanz-López}

The Pyrenean successions show a great spatial variation on the distribution of sedimentary facies, particularly during the Devonian, where a plethora of local lithostratigraphic units have been differentiated (Fig. 8.15). Consequently, detailed description and reference to the original studies are here avoided, since it overpasses the subject of this synthesis. It may be found in extended and recent publications (Dégardin 1988; Sanz-López 1995, 2002a, b, 2004; Dégardin et al. 1996; Delvolvé et al. 1996; García-López et al. 1996; Majesté-Menjoulas et al. 1996; García-Alcalde et al. 2002). Sanz-López (2002a, 2004) described several sedimentary domains modifying the previous Devonian facies-area defined in the Pyrenean Axial zone (Mirouse 1966; Mey 1967, 1968; Boersma 1973; Zwart 1979) and the Basque massifs (Heddebaut 1975) (Fig. 8.16). The western margin of the preserved basin is characterized by the occurrence of a sedimentary hiatus between the Ordovician and Upper Devonian rocks (Basque Cinco Villas domain, CVd; Fig. 8.15). The southern margin is interpreted since shallow-water carbonate platforms are located in a southern belt (Fig. 8.16), and siliciclastic systems were fed from the current south (the Cantabro-Ebroan massif after Mey 1967; Llopis Lladó et al. 1968; Requadt 1974; Carls 1988). An intra-Devonian, or Devonian-late Tournaisian hiatus, is usually recognized in the southernmost successions (Mirouse 1966). Subsidence rates were decreasing and, in parallel, deep-water conditions were increasing along the marginal southern belt from west to east; from the southern Alduides-Mendibeltza to the Sallent, Baliera, Sierra Negra and el Comte domains (AMd, Sd, Bd, SNd and ECd; Fig. 8.16). The norhern belt represents a deep-water epicontinental basin where a condensed carbonate sedimentation prevailed (Northern and Eastern domains, $\mathrm{Nd}$ and $\mathrm{Ed}$ ), although shallow-water facies with sedimentary hiatus also occur in the westernmost part (Ferrières domain, Fd). Among the southern and northern belts, an asymmetric central trough (Central domain, $\mathrm{Cd}$ ) differentiated from the Eifelian to the Tournaisian (Fig. 8.15). The highest subsidence was located at the southern margin probably in relation to fault activity, mainly in the early Frasnian, when the occurrence of extensional listric faults bounding some blocks was interpreted (Majesté-Menjoulas et al. 1991). The siliciclastic supplies filling this trough came from the west highly subsiding area (AMd). Siliciclastic input piled up in the southern part of the trough and disappeared toward the east and the north.

The Silurian sedimentation was onlapping and transgressive, covering the Late Ordovician rifting basins throughout the Pyrenees. Deposition of black carbonaceous shales (Lower Graptolitic Shales after Schmidt 1931 in Fig. $8.15 ; 70-180 \mathrm{~m}$ thick) on a poorly oxygenated bottom sea characterized the Pyrenees as other Variscan areas of southern Europe and northern Africa (García-López et al. 1996). Late Rhuddanian to Aeronian (Llandovery) graptolites are traditionally the lowermost described in black shales of many Pyrenean sections (Dégardin 1988). Late Hirnantian (latest Ordovician) and basal Llandovery graptolites are known in a single locality (Roqué Bernal et al. 2017). The early Llandovery may be recorded by sandy shales without graptolites or by shallow-water deltaic sandstones of the Bar Formation in the southern part of the Central and Eastern Pyrenees. The drowning of this sandy platform seems to have been diachronous, because Aeronian-Telychian graptolites and Llandovery conodonts were described from the transition interval (Llopis Lladó 1969; Sanz-López and Sarmiento 1995). Furthermore, black shales are usually a common detachment horizon.

Condensed carbonate and/or reworking beds with mainly mollusks recorded occasional oxygenation events in the deep basin (Orthoceras Limestone after Dalloni 1913). It may constitute a composite horizon, 5-15 m thick, with Gorstian-Lutfordian (Ludlow) conodonts, although upper Wenlock to lower Prídolí beds are also known (García-López et al. 1996; Sanz-López et al. 2002c). Locally, condensed crinoidal limestones with corals were interpreted as an early Wenlock sedimentary high in the central Pyrenees (Marxant Limestone after Sanz-López and Palau 2000). In the southern, central Pyrenees, ochre condensed and bioturbated carbonates of type Ockerkalk replaced to the Orthoceras Limestone between the early Ludlow and the latest Prídoli (Llessui Formation and Toloriu Limestone; see Sanz-López et al. 2002c). This Ockerkalk facies was deposited on swells or ridges areas and could be in the subsurface of the Ebro basin, because it crops out in the Catalan Coastal Range and is known in the External Nappe zone of Sardinia.

The carbonate deposition and oxygenation of the sea-bottom in the Axial zone coincided with the arrival of distal siliciclastic deposits from the Ludlow in the higher subsiding Basque AMd (Arnéguy Formation; Requadt 1974). There, a shoaling interval is recognized trough Prídolí and early Lockhovian shallow-water faunas (Heddebaut 1975; Requadt 1974). At this time, it corresponds with the east extension of the distal siliciclastic sedimentation 


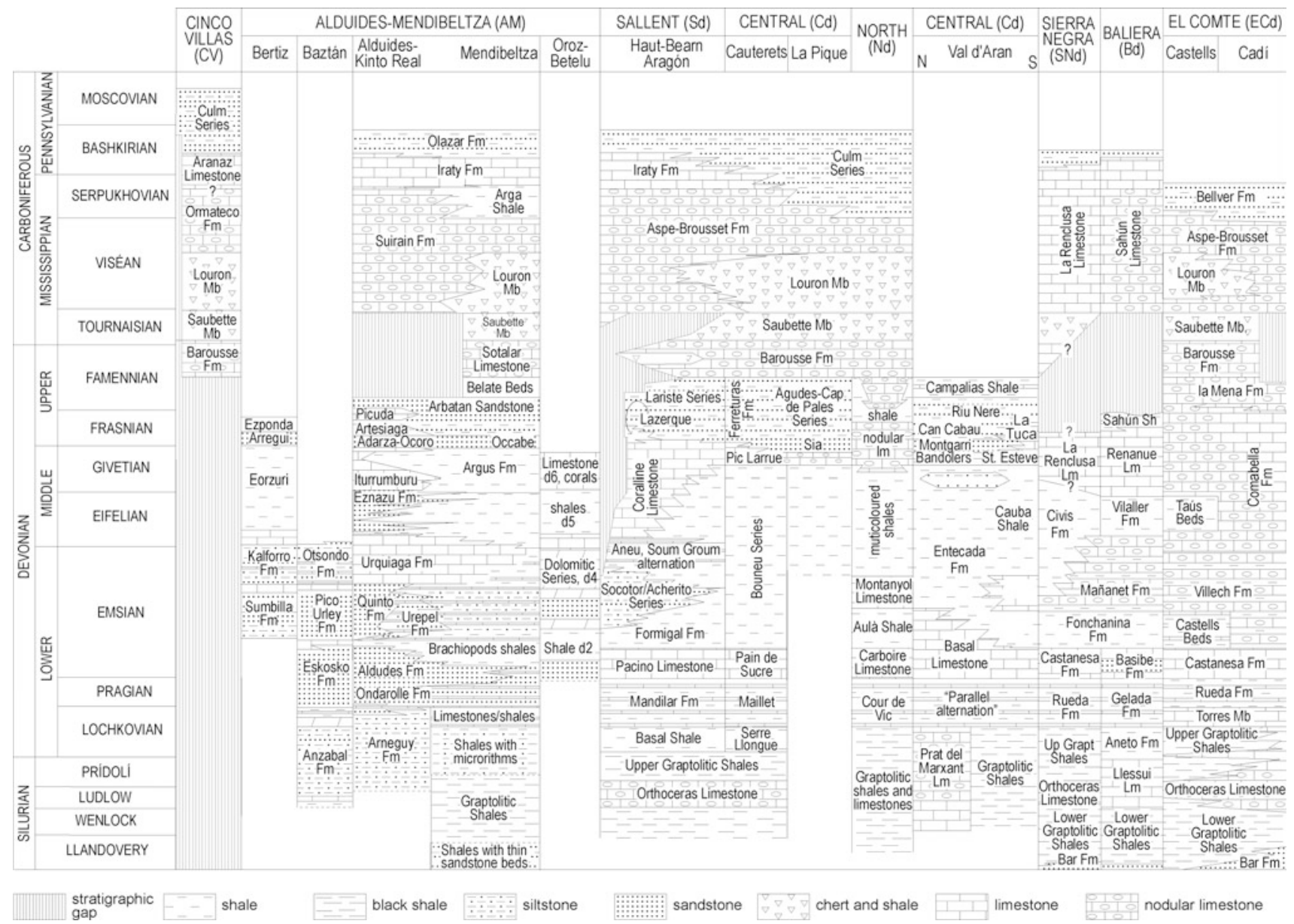

Fig. 8.15 Correlation chart among the Silurian to Middle Pennsylvanian lithostratigraphic units described in the different sedimentary domains. Explanation of units is in the text

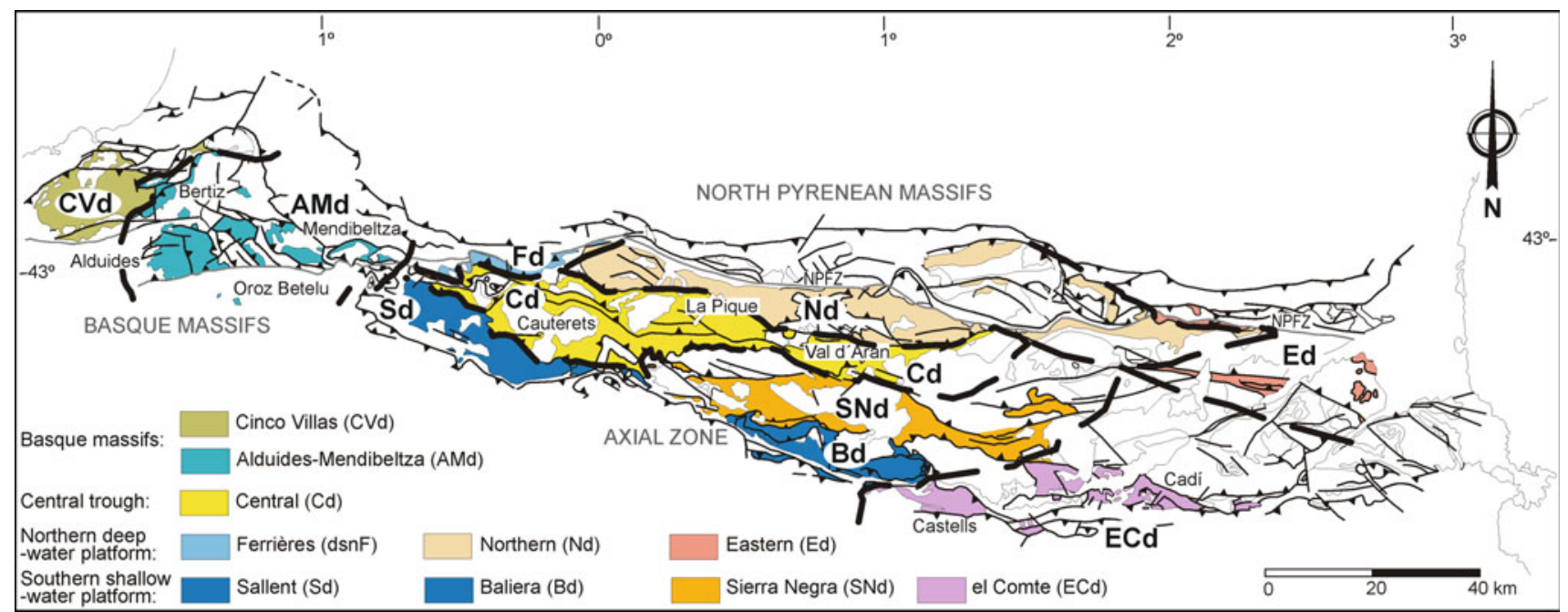

Fig. 8.16 Geological sketch of the Paleozoic rocks in the Pyrenees (Basque massifs, Axial zone and North Pyrenean massifs-north of the North Pyrenean Fault zone, NPFZ) showing the sedimentary domains differentiated for the Silurian to Middle Pennsylvanian rocks 
eastward in the Axial zone (Serre Llongue Shale in the Sd, Aneto Formation in the Bd; 40-80 m thick), although black shale and limestone (Upper Graptolitic Shales; 20-40 m) were restricted to the oxygen depleted basin ( $\mathrm{Sd}, \mathrm{SNd}$ and ECd) and condensed crinoidal limestone deposited on sedimentary highs (ECd). Prídolí to early Lochkovian conodonts, graptolites, chitinozoans and a varied of invertebrate fauna are known (Dégardin 1988; Sanz-López et al. 1999).

A highstand sea-level interval ended the prevalent stratified water and black shale deposition in the Pyrenean Basin. It is recorded in the Torres Member of the ECd (Rueda Formation; $10-20 \mathrm{~m}$ thick) or the equivalent units locally described in the $\mathrm{Bd}, \mathrm{Nd}$ and Ed. It consists of condensed carbonate hemipelagic sedimentation with bioturbated sea-bottom and occasional hardground development. A high resolution conodont zonation spans the mid to late Lochkovian (Valenzuela-Ríos et al. 2015). In the western part of the basin (AMd), shallow water sedimentation corresponds to crinoidal limestones and shales with brachiopods (200 m thick; Klarr 1974).

Siliciclastic input and high subsidence occurred in the AMd during the Pragian (200-700 m of sandstones, shales and quartzites of the Ondarelle and Aldudes formations) in coincidence with a change from extremely hot Lochkovian to hot and humid Pragian climate conditions according to Slavík et al. (2016), and a worldwide sea level lowering (Johnson et al. 1985). A well-oxygenated basin recorded the development of a vast extended Pragian ramp with a distal siliciclastic component (limestones and shales of the Mandilar, Gelada and Rueda formations, 50-120 m thick).

The Aldudes siliciclastic system was retrograding during the late Pragian-early Emsian in the western AMd, and was replaced by 100-200 m of "Brachiopod Shale" (Klarr 1974). In most parts of the Pyrenees, a carbonate ramp with moderate subsidence was onset (Basibé, Castanesa and Pacino formations; $30-60 \mathrm{~m}$ thick). In the Central Pyrenees, a late Pragian siliciclastic wedge prograded northward (San Silvestre Member of the Basibé Formation in the Bd). The carbonate platform shows early Emsian local coralline growth developed on sedimentary highs (ECd; Sanz-López 1995).

An important deepening of the sedimentation occurred during the early Emsian, but it was subdivided into several pulses (from the Middle $P$. excavatus to the Upper P. nothorperbonus conodont Zones; Sanz-López 2002a, b; Martínez-Pérez and Valenzuela-Ríos 2014). Shallow-water mixed siliciclastic-carbonate sedimentation was located in the AMd (Quinto and Urepel formations, 500-600 m thick), while shaly input extended in the Central Pyrenees (Formigal Formation in the Sd, Fonchanina Formation in the $\mathrm{Bd}$ and SNd, Aulà Shales in the Nd; Fig. 8.15). Shale sedimentation was replaced by condensed limestone with dacrioconarids in the ECd (less than $30 \mathrm{~m}$ thick of the
Castells Beds). In the late Emsian, a prevailing carbonate sedimentation with reefal development occurred in the AMd (Urquiaga Formation; $500 \mathrm{~m}$ ). The reduction of mud supply into the southern Pyrenees is related to hemipelagic carbonate sedimentation with deep-water dacrioconarids, ostracods and ammonoids in the Bd and SNd (Mañanet Formation; 280 m thick; García-López et al. 1990). More condensed and carbonate deposition is recorded by the Villech Formation in the distal Eastern Pyrenees (ECd; 35$70 \mathrm{~m}$ thick). Local changes among successions were related to the location in the basin and slopes of sedimentary highs where limestone with coral biostromes may occur (Dalloni 1930; Cavet 1957). A drowning event was recognized at the top of the Villech Fomation (upper Emsian) and followed by the progradation of resedimented carbonate of the Comabella Formation in the ECd (Sanz-López 1995; Montesinos and Sanz López 1999). Late Emsian to basal Eifelian distal siliciclastic wedges arrived to the Western Pyrenees (Socotor and Acherito Beds in the $\mathrm{Sd}$ and $\mathrm{Fd}$ ) and limestone beds yielded brachiopods from the Emsian-Eifelian interval (Requadt 1974; Juch and Schafer 1974; García-Alcalde et al. 2002). Distal siliciclastic deposits were sedimented in the deepest and subsiding areas of the Central Pyrenees (Vilaller Formation in the Bd and SNd; Boneu and Entecada formations in the $\mathrm{Cd}$ ).

The early Eifelian corresponds to a new episode of siliciclastic progradation characterized by sandstones rich in iron oxides in the southern part of AMd (Eznazu Formation, about $200 \mathrm{~m}$ in thickness). Thick successions of shales extended along the Central Pyrenees (Vilaller, Boneu and Entecada formations) as a wedge of condensed shales and marls with abundant dacriconarids in the deep-water nodular limestones of the Comabella Formation deposited in the Ed and the ECd (Taús Beds in Montesinos and Sanz López 1999).

High subsidence and growth of shallow-water reefal limestone is recorded during the latest Eifelian to early Givetian in the Sd and Fd, the Coral Limestone (150-500 m thick; Mirouse 1966; Joseph and Tsien 1975; Joseph et al. 1980 , 1984). It seems to be equivalent to the Iturrumburu Limestone in the southernmost part of the AMd (Chesterikoff 1964; Wirth 1967). The prograding of outer carbonate platform above shales is also recorded from the latest Eifelian in the Bd (Renanue Formation in the central Pyrenees). Slope-apron carbonate bodies were prograding above hemipelagic carbonates derived from reefal biostromes in the ECd.

The mid-Givetian to early Frasnian interval corresponds to the decreasing in the distal siliciclastic sources and highstand sea level. Reefal growth extended to the southern margin of the Cd (Sant Esteve Limestone) and deep-water carbonate sedimentation (dacrioconarid limestone) occurred in the central trough, the Northern and Eastern Pyrenees 
(Bandolers, Gabiedou and Pic de Larrue limestones; Perret et al. 1972; Bodin 1988; Palau and Sanz 1989; García-López et al. 1991). The shale sedimentation was confined to the western highly subsiding margin of the basin in the AMd (Argus Shale, 800-1000 m thick).

Differential subsidence increased probably in relation with extensional tectonics and an early Frasnian compartmented palaeogeography has been suggested (Raymond 1987; Sanz-López 1995). The proximal siliciclastic deep sea-fan deposits occurred in the southern margin of the high subsiding trough in the Cd (Les Bordes Sandstone; Kleinsmiede 1960). The input should be located at the west, concretely in the AMd, where early Frasnian 800-1500 m of shallowwater sandstones and shales deposited as deltaic systems (Irurita Group; de Boer et al. 1974). The trough is not recognizable eastwards, in the Tor-Casamanya syncline, where Givetian to Frasnian nodular limestones and shales were recently described (Clariana 2015). The siliciclastic supplies decreased in the middle Frasnian, but high subsidence continued as shale deposition in the AMd (500 m thick of the Artesiaga Shale). In this line, the Givetian coralline reefal development in the southern belt was retrograding southwards from the Middle-Middle $M$. asymmetricus conodont zones ( $\mathrm{Sd}, \mathrm{Bd}$ and southern $\mathrm{ECd}$ ), may be in relation to the tilting of the southern basin margin. Siliciclastic facies and carbonates resedimented beds deposited in the outer platform (Lazerque and Lariste series, Ferreturas Formation, Sahún Shale) and arrived to the southern part of the Cd (La Tuca Shale and limestone), whereas distal deep sea fans deposits filled the central and northern parts of the central trough (Riu Nere Sandstone and shale, Tourmalet unit). Condensed and deep-water hemipelagic limestone deposited laterally in the epicontinental basin of the $\mathrm{Nd}, \mathrm{Ed}$ and $\mathrm{ECd}$. Frasnian intraformational breccias, slope deposits and local reefal growth suggest the occurrence of swollen areas probably bounded by faults in the ECd (Sanz-López 1995, 2002b). Shallow-water sandstones and bioclastic limestones with brachiopods and corals (Arbartán and Picuda formations; 60-120 m thick) suggest a late Frasnian shoaling in the AMd.

The uppermost Frasnian deepening pulse is characterized by poorly oxygenated shale sedimentation, which included tempestite limestone beds in the lower Famennian of the AMd (Belate Beds, $30 \mathrm{~m}$ thick). It is not differentiated in the outer platform deposits of the Sd and in the distal siliciclastic turbidites of the $\mathrm{Cd}$. A deepening horizon corresponding to shales with carbonate nodules and ammonoids was described in the hemipelagic north and east carbonate sedimentation, and deep-water nodular limestone buried coralline limestone in successions of the Comabella Formation (ECd; Sanz-López 2002b).

The Frasnian/Famennian boundary was correlated with a condensed shale horizon in the Comabella Formation, where a sharp change in the conodont and ostracod faunas occurred in relation to the global Kellwasser Event (Sánchez de Posada et al. 2008). In the Cadí nappe, the Frasnian/ Famennian boundary is located at the base of the La Mena Formation, red limestone with brachiopod shoals and derived tempestistes deposited on sedimentary highs (Sanz-López 2002b). The succession shows a lower-middle Famennian deepening sequence, where cephalopod "Griotte" limestone deposited on the slope and basin. The $\mathrm{La}$ Mena Formation is a condensed, reddish, nodular limestone with cephalopods (12-30 m thick) deposited in the basinal area of the ECd, Ed and part of the Nd (Bouquet and Stoppel 1975; Cygan 1979). At time, anoxic deep-water black shale sedimentation with resedimented limestone beds deposited in the central trough (Campalias Shale) and in the AMd (Belate Beds), whereas siliciclastic beds of the Ferreturas Formation seems to be the lateral equivalent in the southern Pyrenean belt.

The Barousse Formation consists of nodular cephalopodbearing limestones (25-70 $\mathrm{m}$ thick) deposited during the mid Famennian to the early Tournaisian. It formed a deep-water, starved, carbonate ramp extending along mostly of the Pyrenees, including the CVd (where it is above Ordovician rocks). This formation marks the beginning of the onlap on the Cantabro-Ebroian block and predated its burial in the upper Tournaisian. The Barousse Formation lacks or is locally preserved, as bioclastic or crinoidal limestone, in the southern part of the Sd. The upper part of the Barousse Formation includes ash and cherts beds in the Sd and AMd (Soques Chert after Perret 1993). At the top, the Boyer et al. (1974)'s horizon B is a continuous shale less than $1 \mathrm{~m}$ in thickness ( $2 \mathrm{~m}$ in the deep basin of the $\mathrm{Cd}$ ) and equivalent to the Rhenish Hangenberg Shale. It is associated with the latest Famennian, global, cooling event and the life extinction crisis (Walliser 1996). The base of the Boyer et al. (1974)'s limestone C of the Barousse Formation (about $2 \mathrm{~m}$ thick) corresponds to a worldwide eustatic rise post-glacial horizon close to the lower boundary of the Carboniferous according to conodont faunas (Boyer et al. 1974; Sanz-López 1995, 2002c; Kaiser et al. 2008). The top of this limestone provided mid Tournaisian conodonts (Siphonodella cooperi or S. crenulata zones).

Above, the Saubette Chert consists of black radiolarian cherts and shales with horizons of phosphatic nodules (Perret 1993). A mid to late Tournaisian age is derived from radiolarians, crustaceans and ammonoids in coincidence with the conodonts obtained in the limestone above and below the chert unit (Delépine 1935; Goumerlon 1987). These poorly oxygenated sediments extended throughout the Pyrenees in coincidence with the worldwide Lower Alum Shale event or Mid-Tournaisian event described by Walliser (1996). It lacks on the southern marginal area and on the sedimentary highs in relation to the tilting of the southern Devonian platform and to extensional tectonics in the $\mathrm{Sd}$ and $\mathrm{Fd}$. These areas 
were drowned by condensed sandy transgressive bioclastic limestones (lowest part of the Aspe-Brousset Formation) with late Tournaisian and reworked Devonian conodonts (Perret 1993; Perret and Weyant 1994). Consequently, the onlap of the marginal area was contemporaneous with the deposition of the upper part of the Saubette Chert in the basin. Tournaisian cherts or limestones are directly overlying different Cambrian to Upper Devonian rocks in the adjacent Palaeozoic outcrops of the current western Mediterranean Sea (Aiguafreda Formation of the Catalonian Coastal Range, cherts and siliceous shales in the Minorque Island and the lower member of the Falcoña Formation in the Betic Chains) indicating a subdivided basin maybe in relation to extensional faults (Raymond and Lethiers 1990). An intraTournaisian hiatus and erosion has also been recognized in the Cantabrian zone (Sanz-López and Blanco-Ferrera 2012). The mid-late Tournaisian starved basins recorded episodic high planktonic productivity and poorly oxygenated bottom-sea, far of siliciclastic supplies and locally related to submarine volcanism. In the southern Catalonian Coastal Range, lava flows derived from alkali basalts solidified in shallow-waters marine setting in an intraplate extensional context (Melgarejo and Martí 1989; Melgarejo 1992).

Complete deep-water sedimentation above sedimentary highs had a maximum flooding event at the late Tournaisian (Scaliognathus anchoralis Conodont Zone). Sedimentation of condensed, nodular to massive, cephalopod limestones (Aspe-Brousset Formation; 25-30 m thick) recorded an increase in the oxygen content of the sea-bottom respect to the mid Tournaisian (Perret 1976; Sanz-López 2002b). A similar episode is known in the Cabrières klippes (Montagne Noire), the Valls unit (Catalonian Coastal Range) and the Cantabrian Mountains, and corresponds to the Avins Event in the Dinant Basin (Poty 2007). Sedimentation of cherts and siliceous shales with inter-bedded graded tuff layers (Louron Member) deposited above the Saubette Chert in the deep part of the Pyrenean basin, including the CVd, eastern AMd, Cd and locally the $\mathrm{Nd}$ and ECd (Krylatov 1963; Crilat 1983; Sanz-López 1995). The lower-middle Viséan cherts are replaced by condensed cephalopod limestone on the swollen areas in a similar line to the described in the Cantabrian Mountains and the Montagne Noire (cherts of the Lavandera Member in the Alba Formation; Colonnes Formation, respectively). The basinal, starved, Tournaisian to lower Viséan chert sedimentation in known in other adjacent Palaeozoic outcrops of the current western Mediterranean Sea-region (Catalonian Coastal Range, Minorque Island, Betic Chains and the Palentine nappes of the Cantabrian Mountains). In all these areas, centimetre-thick fine-grained tuffaceous clayey horizons occurred and suggest volcanism in relation with a faulted, subdivided basin.

Condensed nodular carbonate sedimentation of the Aspe-Brousset Formation extended in the Pyrenees and the western Mediterranean area from the mid to late Viséan ( $G$. praebilineatus to $G$. bilineatus conodont zones). A deeper sedimentation corresponds to the limestone and siliceous shales (Larbont facies of Clin 1959) in the northeastern part of the Pyrenees (ECd, $\mathrm{Cd}$ and $\mathrm{Nd})$. There, the top of the Aspe-Brousset Formation provided conodonts and ammonoid considered late Viséan or early Serpukhovian. This limestone-shale sedimentation was described in the Catalonian Coastal Range (el Papiol Formation; 10-12 m thick) and in Minorque (Bourrouilh 1983; Martínez Chacón et al. 2003). Rich endemic trilobite, brachiopods and coral faunas adapted to quiet water conditions in soft, muddy sea bottom muddy bottoms are known (Martínez Chacón et al. 2003; Plusquellec et al. 2007; Gandl et al. 2015). Shallow-water carbonate shelves grew up north of the Pyrenees during the Viséan and the Serpukhovian. It is preserved in the Mouthoumet massif ("Calcaires à algues et foraminifers" Formation in Bessière and Schulze 1984) and as deposits derived as calciturbidites and debris flows in the Montagne Noire (Colonnes Formation and Puech Capel Formation in Korn and Feist 2007). The arrival of synorogenic siliciclastic supplies of the Culm flysch ended the carbonate sedimentation. It occurred in the late Serpukhovian drowning episode recorded at the top of the Aspe-Brousset Formation in the southern central and western Pyrenees ( $\mathrm{Sd}, \mathrm{Bd}$ and $\mathrm{AMd}$ ). Late Viséan to late Serpukhovian clasts and olistoliths from shallow-water carbonate platforms were reworked in the synorogenic flysch deposits of the Montagne Noire and Pyrenees (Delvolvé et al. 1996; Vachard et al. 2016).

\section{References}

Abad A (1988) El Cámbrico inferior de Terrades (Gerona). Estratigrafía, facies y paleontología. Batallería 2:47-56.

Álvaro JJ, Courjault-Radé P, Chauvel JJ, Dabard MP, Debrenne F, Feist R, Pillola GL, Vennin E, Vizcaïno D (1998) Nouveau découpage stratigraphique des séries cambriennes des nappes de Pardailhan et du Minervois (versant sud de la Montagne Noire, France). Géol Fr 1998 (2):3-12.

Álvaro JJ, Ferretti F, González-Gómez C, Serpagli E, Tortello MF, Vecoli, M, Vizcaïno D (2007) A review of the Late Cambrian (Furongian) palaeogeography in the western Mediterranean region, NW Gondwana. Earth-Sci Rev 85:47-81.

Álvaro JJ, Monceret E, Monceret S, Verraes G, Vizcaïno D (2010) Stratigraphic record and palaeogeographic context of the Cambrian Epoch 2 subtropical carbonate platforms and their basinal counterparts in SW Europe, West Gondwana. Bull Geosci 85:573-584.

Álvaro JJ, Bauluz B, Clausen S, Devaere L, Imaz AG, Monceret E, Vizcaïno D (2014) Stratigraphy of the Cambrian-Lower Ordovician volcanosedimentary complexes, northern Montagne Noire, France. Stratigraphy 11:83-96.

Álvaro JJ, Colmenar J, Monceret E, Pouclet A, Vizcaïno D (2016) Late Ordovician (post-Sardic) rifting branches in the North Gondwanan Montagne Noire and Mouthoumet massifs of southern France. Tectonophysics 681:111-123.

Ayora C (1980) Les concentrationes metàl-liques de la Vall de Ribes. $\mathrm{PhD}$, Univ. Barcelona. 
Ayora C, Casas JM (1986) Strabound As-Au mineralization in pre-Caradocian rocks from the Vall de Ribes, Eastern Pyrenees, Spain. Mineralium Deposita 21:278-287.

Barca S, Carmignani L, Cocozza T, Franceschelli M, Ghezzo C, Memmi I, Minzoni N, Pertusati PC, Ricci CA (1987) The Caledonian events in Sardinia. In The Caledonian Orogen-Scandinavian and related areas. In: Gee DG, Sturt BA (eds) John Wiley ans Sons Ltd, p 1195-1199.

Belaustegui Z, Puddu C, Casas JM (2016) New ichnological data from the lower Paleozoic pf the Central Pyrenees: presence of Artrophycus brogniartii (Harlam, 1832) in the Upper Ordovician Cava Formation. Geo-Temas 16:271-274.

Bessière G, Schulze H (1984) Le Massif de Mouthoumet (Aude, France): nouvelle définition des unités structurales et essai d'une reconstruction paléogéographique. Bull Soc géol Fr 26:885-894.

Bodin J (1988) Le Dévonien inférieur et moyen des Pyrénées ariégeoises et centrales. Biostratigraphie, séries hétéropiques et mise en évidence de nappes hercyniennes précoces. Doc BRGM 153:1-255

Boer HU de, Krausse MF, Mohr K, Pilger A, Requadt H (1974) La région de magnésite d'Eugui dans les Pyrénées Occidentales espagnoles: Une explication de la carte géologique. Pirineos 111:21-39.

Boersma KT (1973) Devonian and Lower Carboniferous biostratigraphy, Spanish Central Pyrénées. Leidse Geol Meded 49:303-377.

Bouquet C, Stoppel D (1975) Contribution à l'étude du Paléozoïque des Pyrénées centrales (Hautes vallées de la Garonne et d'Aure) Bull BRGM (sec 1) 1:7-61.

Bourrouilh R (1983) Estratigrafía, sedimentología y tectónica de la isla de Menorca y del noreste de Mallorca (Baleares). La terminación nororiental de las Cordilleras béticas en el Mediterráneo occidental. Mem IGME 99, Madrid.

Boyer F, Krylatov S, Stoppel D (1974) Sur le problème de l'existence d'une lacune sous les lydiennes à nodules phosphatés du Dinantien des Pyrénées et de la Montagne Noire (France, Espagne). Geol J (B) 9:1-60.

Buzzi L, Funedda A, Gaggero L, Oggiano G (2007) Sr-Nd isotope, trace and REE element geochemistry of the Ordovician volcanism in the southern realms of the Variscan belt. EGU General Assembly 2007, Wien, 15-20 April 2007, Abstract.

Calvet Ph, Lapierre E, Charvet J (1988) Diversité du volcanisme ordovicien dans la région de Pierrefitte (Hautes Pyrénées): rhyolites calco-alcalines et basalts alcalins. C R Acad Sci Paris 3078: 805-812.

Carls P (1988) The Devonian of Celtiberia (Spain) and Devonian paleogeography of SW Europe. Can Soc Petrol Geol Mem 14: 421464.

Carmignani L, Oggiano G, Barca S, Conti P, Salvadori I, Eltrudis A, Funedda A, Pasci S (2001) Geologia della Sardegna. Note illustrative della Carta Geologica della Sardegna a scala 1:200.000. Memorie Descrittive della Carta Geologica d'Italia, Servizio Geologico 60:1-283. Instituto Poligrafico e Zecca dello Stato, Roma.

Casas JM (2010) Ordovician deformations in the Pyrenees: new insights into the significance of pre-Variscan ('sardic') tectonics. Geol Mag 147: 674-689.

Casas JM, Fernández O (2007) On the Upper Ordovician unconformity in the Pyrenees: New evidence from the La Cerdanya area. Geol Acta 5:193-198.

Casas JM, Palacios T (2012) First biostratigraphical constraints on the pre-Upper Ordovician sequences of the Pyrenees based on organic-walled microfossils. C R Géosci 344:50-56.
Casas JM, Castiñeiras P, Navidad M, Liesa M, Carreras J (2010) New insights into the Late Ordovician magmatism in the Eastern Pyrenees: U-Pb SHRIMP zircon data from the Canigó massif. Gondwana Res 17:317-324.

Casas JM, Queralt P, Mencos J, Gratacós O (2012) Distribution of linear mesostructures in oblique folded surfaces: Unravelling superposed Ordovician and Variscan folds in the Pyrenees. J Struct Geol 44:141-150.

Castiñeiras P, Navidad M, Liesa M, Carreras J, Casas JM (2008) U-Pb zircon ages (SHRIMP) for Cadomian and Lower Ordovician magmatism in the Eastern Pyrenees: new insights in the pre-Variscan evolution of the northern Gondwana margin. Tectonophysics 46:228-239.

Castiñeiras P, Navidad M, Casas JM, Liesa M, Carreras J (2011) Petrogenesis of Ordovician magmatism in the Pyrenees (Albera and Canigó Massifs) determined on the basis of zircon minor and trace element composition). J Geol 119:521-534.

Cavet P (1957) Le Paléozoïque de la zone axiale des Pyrénées orientales françaises entre le Roussillon et l'Andorre. Bull Serv Carte géol Fr 55:303-518.

Chesterikoff A 1964 Note sur l'existence d'un palédôme dans la région de Burguete-Arive-Arrieta (Pyrénées basques espagnoles) et ses relations métallogéniques avec les mineralizations périphériques. Bull Soc géol Fr (6) 8:225-232.

Cirés J, Casas JM, Muñoz JA, Fleta J, Barbera M (1994) Memoria explicativa del mapa geológico de España a escala 1:50.000, hoja de Molló (n²18). ITGE, Madrid.

Clariana P (2015) Estratigrafía, estructura y su relación con el metamorfismo de la Zona Axial pirenaica en la transversal del Noroeste de Andorra y comarcas del Pallars Sobirá y el Alt Urgell (Lleida). Dissertation, University of Oviedo.

Clin M (1959) Etude géologique de la haute chaine des Pyrénées Centrales entre le cirque de Troumouse et le cirque du Lys. Dissertation, University of Nancy.

Cocherie A, Baudin Th, Autran A, Guerrot C, Fanning C.M, Laumonier B (2005) U-Pb zircon (ID-TIMS and SHRIMP) evidence for the early Ordovician intrusion of metagranites in the late Proterozoic Canaveilles Group of the Pyrenees and the Montagne Noire (France). Bull Soc géol Fr 176:269-282.

Crilat S (1983) Le Devonien supérieur et le Carbonifère inférieur des Pyrénées et de la Montagne Noire (Frasnien, Famennien, Tournaisien). Newsl IGCP 5:231-254.

Cygan C (1979) Etude de conodontes dévoniens des Pyrénées et du massif de Mouthoumet. Dissertation, University of Toulouse.

Dalloni M (1913) Stratigraphie et tectonique de la région des Nogueras (Pyrénées centrales). Bull Soc géol Fr (sér 4) 1:243-263.

Dalloni M (1930) Etude géologique des Pyrénées Catalanes. An Fac Sci Marseille 26, 3:1-373.

Dégardin JM (1988) Le Silurien des Pyrénées. Biostratigraphie. Paléogéographie. Bull Soc géol Nord 15:1-355.

Dégardin JM (coord) et al (1996) Ordovicien supérieur-Silurien. In: Barnolas A, Chiron JC, Guérangué B (eds) Synthèse géologique et géophysique des Pyrénées vol 1. Editons BRGM-ITGE, Orléans, Madrid, pp 211-233.

Delépine G (1935) Contribution a l'étude de la faune du Dinantien des Pyrénées Deuxième partie: la faune de Mondette. Bull Soc géol Fr (sér 5) 5:171-189.

Deloule E, Alexandrov P, Cheilletz A, Laumonier B, Barbey P (2002) In-situ U-Pb zircon ages for Early Ordovician magmatism in the eastern Pyrenees, France: the Canigou orthogneisses. Int J Earth Sci 91:398-405. 
Delvolvé JJ et al (1996) Carbonifère à faciès Culm In Barnolas A, Chiron JC (eds) Synthèse géologique et géophysique des Pyrénées vol 1. Editions BRGM-ITGE, Orléans, Madrid, pp 303-338.

Den Brok SWJ (1989) Evidence for pre-Variscan deformation in the Lys Caillaouas area, Central Pyrenees, France. Geol Mijnbouw 68:377-380.

Denèle Y, Barbey P, Deloule E, Pelleter E, Olivier Ph, Gleizes G (2009) Middle Ordovician U-Pb age of the Aston and Hospitalet orthogneissic laccoliths: their role in the Variscan evolution of the Pyrenees. Bull Soc géol Fr 180:209-221.

DePaolo DJ (1981) Neodymiun isotopes in the Colorado Front range and crust-mantle evolution in the Proterozoic. Nature 291:193-196.

DePaolo DJ, Wasserburg GJ (1976) Nd isotopic variations and petrogenetic models. Geophys Res Lett 3 (5):249-252.

Devaere L, Clausen S, Steiner M, Álvaro JJ, Vachard D (2013) Chronostratigraphic and palaeogeographic significance of an early Cambrian microfauna from the Heraultia Limestone, northern Montagne Noire, France. Palaeonto Electr 16(2), 17A:1-91.

Devaere L, Clausen S, Monceret E, Vizcaïno D, Vachard D, Genge MC (2014) The tommotiid Kelanella and associated fauna from the early Cambrian of southern Montagne Noire (France): implications for Camenellan phylogeny. Palaeontology 57:979-1002.

Di Pisa A, Gattiglio M, Oggiano G (1992) Pre-Hercynian magmatic activity in the nappe zone (internal and external) of Sardinia: evidence of two within plate basaltic cycles. In Carmingnani L, Sassi F P (eds) Contributions to the Geology of Italy with Special Regard to the Paleozoic Basements. Newsletter IGCP no. 276:107-116.

Funedda A, Oggiano G (2009) Outline of the Variscan basement of Sardinia. In: Corradini C, Ferretti A, Štorch P (eds) The Silurian of Sardinia. Volume in Honour of Enrico Serpagli. Rendicontti della Società Paleontologica Italiana 3:23-35.

Gámez Vintaned JA, de Gibert JM, Casas JM (2012) First ichnological data from the pre-Upper Ordovician rocks of the Pyrenees. Geo-Temas 13.

Gandin A, Pillola GL (1985) Biostratigrafia e sedimentologia della Formazione di Cabitza nell'Iglesiente. In: Gruppi di lavoro del CNR: "Paleozoico" e "Evoluzione magmatica e matemorfica della costra fanerozoica". Riunione Scientifica Siena, 13-14 Decembre 1985, 30-31.

Gandl J, Ferrer E, Magrans J, Sanz-López J (2015) Trilobiten aus dem Unter-Karbon des Katalonischen Küstengebirges (NE-Spanien). Abh Senckenberg Ges Naturforsch 571, Schweizerbart and Borntraeger Science Publishers, Stuttgart.

García-Alcalde JL, Carls P, Pardo-Alonso MV, Sanz-López J, Soto FM, Truyols-Massoni M, Valenzuela-Ríos JI (2002) Devonian. In: Gibbons W, Moreno MT (eds) The Geology of Spain. Geol Soc London, pp 67-91.

García-López S, García-Sansegundo J, Arbizu M (1990) Datos estratigráficos y paleontológicos de la sucesión devónica del área del río Baliera (Zona Axial, Pirineos centrales españoles). Geogaceta 7:33-35.

García-López S, García-Sansegundo J, Arbizu M (1991) Devonian of the Aran Valley Synclinorium, Central Pyrenees, Spain: Stratigraphical and Paleontological data. Acta Geol Hisp 26 (1):55-66.

García-López, S, Rodríguez-Cañero R, Sanz-López J, Sarmiento GN, Valenzuela-Ríos JI (1996) Conodontos y episodios carbonatados en el Silúrico de la Cadena hercínica meridional y el Dominio Sahariano. Rev Esp Paleontol, num extr: 33-57.

García-Sansegundo J, Alonso JL (1989) Stratigraphy and structure of the southeastern Garona Dome. Geodin Acta 3:127-134.

García-Sansegundo J, Gavaldà J, Alonso JL (2004) Preuves de la discordance de l'Ordovicien supérieur dans la zone axiale des Pyrénées: exemple de dôme de la Garonne (Espagne, France). C R Géosci 336:1035-1040.
Gil-Peña I, Sanz-López J, Barnolas A, Clariana P (2000) Secuencia sedimentaria del Ordovícico superior en el margen occidental del domo del Orri (Pirineos Centrales). Geotemas 1:187-190.

Gil-Peña I, Barnolas A, Villas E, Sanz-López J (2004) El Ordovícico Superior de la Zona Axial. In Vera JA (ed) Geología de España. SGE-IGME, Madrid, p 247-249.

Goumerlon F (1987) Les radiolaires tournaisiens des nodules phosphatés de la Montagne Noire et des Pyrénées Centrales. Systematique-Biostratigraphie-Paleobiogeographie. Biostratigraphie du Paléozoïque 6:1-172.

Guitard G (1970) Le métamorphisme hercynien mésozonal et les gneiss œillés du massif du Canigou (Pyrénées orientales). Mém BRGM 63:1-353.

Hartevelt JJA (1970) Geology of the upper Segre and Valira valleys, central Pyrenees, Andorra/Spain. Leid Geol Meded 45:167-236.

Heddebaut C (1975) Etudes géologiques dans les Massifs paléozoïques basques (résumé de thèse). Bull BRGM 4 (2):5-30.

Johnson JG, Klapper G, Sandberg CA (1985) Devonian eustatic fluctuations in Euramerica. Geol Soc Am Bull 96:567-587.

Joseph, J, Brice D, Mouravieff N (1980) Données paléontologiques nouvelles sur le Frasnien des Pyrénées centrales et occidentales: implications paléogéographiques. Bull Soc Hist Nat Toulouse 116:16-41.

Joseph J, Mirouse R, Perret MF (1984) Calcaires dévoniens et carbonifères du Monte Tobazo (Pyrénées aragonaises, Huesca, Espagne). Acta Geol Hisp 19:149-166.

Joseph J, Tsien HH (1975) Calcaires mésodévoniens et leurs faunes de tétracoralliaires en haute vallée d'Ossau (Pyrénées Atlantiques). Bull Soc Hist Nat Toulouse 111:179-202.

Juch D, Schafer D (1974) L'Hercynien de Maya et de la vallée d'Arizakum dans la partie orientale du massif de Cinco-Villas (Pyrénées Occidentales de Espagne). Pirineos 111:41-58.

Kaiser S I, Steuber T, Becker RT (2008) Environmental change during the Late Famennian and Early Tournaisian (Late Devonian-Early Carboniferous) implications from stable isotopes and conodont biofacies in southern Europe. In: Aretz M, Herbig H-G, Somerville ID (eds) Carboniferous Platforms and Basins. Geol J 43:241-260.

Klarr K (1974) La structure géologique de la partie sud-est du Massif des Aldudes-Quinto Real (Pyrénées Occidentales). Pirineos 111:59-67.

Kleinsmiede WJF (1960) Geology of the valle d'Aran (Central Pyrenees). Leidse Geol Meded 25:129-245.

Korn D, Feist R (2007) Early Carboniferous ammonoid faunas and stratigraphy of the Montagne Noire (France). Fossil Record 10:99-124.

Kriegsman LM, Aerden DGAM, Bakker RJ, den Brok SWJ, Schutjens PMTM (1989) Variscan tectonometamorphic evolution of the eastern Lys-Caillaouas massif, Central Pyrenees-evidence for late orogenic extension prior to peak metamorphism. Geol Mijnbouw 68:323-333.

Krylatov S (1963) Note préliminaire sur les jaspes dinantiens des Pyrénées et leur cortège). Bull Soc géol Fr (sér 7) 5:393-400.

Laumonier B (1988) Les groupes de Canaveilles et de Jujols ("Paléozoïque inférieur") des Pyrénées orientales - arguments en faveur de l'âge essentiellement Cambrien de ces séries. Hercynica 4:25-38.

Laumonier B, Guitard G (1986) Le Paléozoïque inférieur de la moitié orientale de la Zone Axiale des Pyrénées. Essai de synthèse. C R Acad Sci Paris 302:473-478.

Laumonier B, Abad A, Alonso JL, Baudelot S, Bessière G, Besson M, Bouquet $\mathrm{C}$, Bourrouilh $\mathrm{R}$, Brula $\mathrm{P}$, Carreras $\mathrm{J}$, Centène $\mathrm{A}$, Courjault-Radé R, Courtessole R, Fauconnier D, García-Sansegundo J, Guitard G, Moreno-Eiris E, Perejón A, Vizcaïno D (1996) In: Barnolas A, Chiron JC (eds) Synthèse géologique et géophysique des Pyrénées. Tome 1: Cycle hercynien. Cambro-Ordovicien. BRGM-ITGE, Orléans-Madrid. p 157-209. 
Laumonier B, Autran A, Barbey P, Cheilletz A, Baudin T, Cocherie A, Guerrot C (2004) Conséquences de l'absence de socle cadomien sur l'âge et la signification des séries pré-varisques (anté-Ordovicien supérieur) du sud de la France (Pyrénées, Montagne Noire). Bull Soc géol Fr 175:105-117.

Laumonier B, Calvet M, Wiazemsky M, Barbey P, Marignac C, Lambert J, Lenoble JL (2015) Notice explicative de la Carte géologique de la France (1/50.000), feuille Céret (1096). BRGM, Orléans.

Liesa M, Carreras J (1989) On the structure and metamorphism of the Roc de Frausa Massif (Eastern Pyrenees). Geodin Acta 3:149-161.

Liesa M, Carreras J, Castiñeiras P, Casas JM, Navidad M, Vilà M (2011) U-Pb zircon age of Ordovician magmatism in the Albera Massif (Eastern Pyrenees). Geol Acta 9:1-9.

Loi A, Pillola GL, Leone F (1995) The Cambrian and Early Ordovician of south-western Sardinia. In: 6th Paleobenthos International Symposium, October, 25-31 1995. Rendiconti del Seminario della Facoltà di Scienze dell'Università di Cagliari (suppl. vol. 65): 63-81.

Llopis Lladó N (1965) Sur le Paléozoïque inférieur de l'Andorre. Bull Soc géol Fr 7:652-659.

Llopis Lladó N (1969) Estratigrafía del Devónico de los valles de Andorra. Mem R Acad Cien Art Barcelona 39:219-290.

Llopis Lladó N, de Villalta JF, Cabanas R, Pelaez Pruneda JR, Vilas L (1968) Le Dévonien de l'Espagne. Int Symp Devonian System, Calgary (1967) 1, pp 171-187.

Majesté-Menjoulas C, Debat C, Mercier A (1991) Les massifs anciens des Pyrénées. Sci Geol Bull 44:337-369.

Majesté-Menjoulas C, Ríos LM (coord) et al (1996) Dévonien-Carbonifère inférieur. In: Barnolas A, Chiron JC, Guérangué B (eds) Synthèse géologique et géophysique des Pyrénées vol 1. Editons BRGM-ITGE, Orléans, Madrid, pp 235-301.

Margalef A (2015) Estudi estructural i estratigràfic del sud d'Andorra. $\mathrm{PhD}$, Univ. Barcelona.

Margalef A, Castiñeiras P, Casas JM, Navidad M, Liesa M, Linnemann U, Hofmann M, Gärtner A (2016) Detrital zircons from the Ordovician rocks of the Pyrenees: Geochronological constraints and provenance. Tectonophysics 681:124-134.

Martí J, Muñoz JA, Vaquer R (1986) Les roches volcaniques de l'Ordovicien supérieur de la région de Ribes de Freser-Rocabruna (Pyrénées catalanes): caractères et signification. C R Acad Sci Paris 302:1237-1242.

Martí J, Casas JM, Guillén N, Muñoz JA, Aguirre G (2014) Structural and geodynamic constraints of Upper Ordovician volcanism of the Catalan Pyrenees. Gondwana 15 Abstracts book, 104.

Martínez F, Iriondo A, Dietsch C, Aleinikoff JN, Peucat JJ, Cirès J, Reche J, Capdevila R (2011) U-Pb SHRIMP-RG zircon ages and $\mathrm{Nd}$ signature of lower Paleozoic rifting-related magmatism in the Variscan basement of the Eastern Pyrenees. Lithos 127:10-23.

Martínez Catalán JR (2012) The Central Iberian arc, an orocline centered in the Iberian Massif and some implications for the Variscan belt. Int J Earth Sci 101:1299-1314.

Martínez Chacón ML, Winkler Prins CF, Sanz-López J, Ferrer E, Magrans J (2003) Braquiópodos misisípicos de los alrededores de Barcelona (Cadenas Costeras Catalanas, NE España). Rev Esp Paleontol 18:189-204.

Martínez-Pérez C, Valenzuela-Ríos JI (2014) New Lower Devonian polygnathids (Conodonta) from the Spanish Central Pyrenees, with comments on the early radiation of the group. J Iber Geol 40:141-155.

Melgarejo JC (1992) Estudio geológico y metalogenético del Paleozoico del sur de las Cordilleras Costeras Catalanas. Mem ITGE 103.

Melgarejo JC, Martí J (1989) El vulcanisme bàsic del Carbonífer inferior de la serra de Miramar. Acta Geol Hisp 24:131-138.

Mey PHW (1967) The Geology of the upper Ribagorzana and Baliera valleys, Central Pyrenees, Spain. Leidse Geol Meded 41:153-220.
Mey PHW (1968) Evolution of the Pyrenean Basins during the Late Paleozoic. Internat Symp Devonian System, Calgary (1967) 1, pp 1157-1166.

Mezger J, Gerdes A (2016) Early Variscan (Visean) granites in the core of central Pyrenean gneiss domes: implications from laser ablation $\mathrm{U}-\mathrm{Pb}$ and Th-Pb studies. Gondwana Res 29:181-198.

Mirouse R (1966) Recherches géologiques dans la partie occidentale de la zone primaire axiale des Pyrénées. Mém Carte géol Fr, Paris.

Montesinos JR, Sanz López J (1999) Ammonoideos del Devónico Inferior y Medio en el Pirineo Oriental y Central. Antecedentes históricos y nuevos hallazgos. Rev Esp Paleontol, num extr: 97-108.

Muñoz JA (1985) Estructura alpina i herciniana a la vora sud de la zona axial del Pirineu oriental. PhD, Univ. Barcelona.

Muñoz JA (1992) Evolution of a continental colision belt: ECORS-Pyrenees crustal balanced cross-section. In: Mc Clay KR (ed) Thrust Tectonics, Chapman \& Hall, London, p 235-246.

Muñoz JA, Casas JM (1996) Tectonique préhercynienne. In: Barnolas A, Chiron JC (eds) Synthèse géologique et géophysique des Pyrénées, BRGM-ITGE, Orléans-Madrid, p 587-1589.

Navidad M, Castiñeiras P, Casas JM, Liesa M, Fernández-Suárez J, Barnolas A, Carreras J, Gil-Peña I (2010) Geochemical characterization and isotopic ages of Caradocian magmatism in the northeastern Iberia: insights into the Late Ordovician evolution of the northern Gondwana margin. Gondwana Res 17:325-337.

Navidad M, Casas J M, Castiñeiras P, Liesa M, Belousova E, Proenza J, Aiglsperger Th (2018) Ordovician magmatism in northern Gondwana: Evolution based on new U-Pb geochronology, whole-rock geochemistry, and $\mathrm{Nd}$ isotopes in orthogneisses and metabasic rocks from the Eastern Pyrenees. Lithos 314-315, 479-496.

Padel M (2016) Influence cadomienne dans les séries pré-sardes des Pyrénées Orientales: approche géochimique, stratigraphique et géochronologique. PhD Thesis. University of Lille I.

Padel M, Álvaro JJ, Clausen S, Guillot F, Poujol M, Chichorro M, Monceret E, Pereira MF, Vizcaïno D (2017) U-Pb laser ablation ICP-MS zircon dating across the Ediacaran-Cambrian transition of the Montagne Noire, southern France. Comptes Rendus Geoscience 349:380-390.

Padel M, Clausen S, Álvaro JJ, Casas JM (2018) Review of the Ediacaran-Lower Ordovician (pre-Sardic) stratigraphic framework of the Eastern Pyrenees, southwestern Europe. Geol Acta 16, 339355 .

Palau J, Sanz J (1989) The Devonian units of the Marimanya Massif and their relationship with the Pyrenean Devonian facies areas. Geodin Acta 3:171-182.

Palme H, O’Neill HSC (2004) Cosmochemical estimates of mantle composition. In: RW Carlson (ed) The mantle and core. Treatise on Geochemistry. HD Holland, HD, Turekian KK (eds), Elsevier-Pergamon, Oxford, 2:1-38.

Pearce JA (1996) Sources and setting of granitic rocks. Episodes 19 (4):120-125.

Pearce JA (2008) Geochemical fingerprinting of oceanic basalts with applications to ophiolite classification and the search for Archean oceanic crust. Lithos 100:14-48.

Pearce JA, Harris NBW, Tindle AG (1984) Trace element discrimination diagrams for the tectonic interpretation of granitic rocks. J Petrol 25:956-983.

Perejón A, Moreno Eiris E, Abad A (1994) Montículos de arqueociatos y calcimicrobios del Cámbrico Inferior de Terraldes, Gerona (Pirineo Oriental, España). Bol R Soc Esp Hist Nat (Sec Geol) 89:55-95.

Perret MF (1976) Une transgression dinantienne dans les Pyrénées occidentales: datation micropaléontologique et analogies. C R somm Soc géol Fr 6:257-259. 
Perret MF (1993) Recherches micropaléontologiques et biostratigraphiques (Conodontes - Foraminifères) dans le Carbonifère pyrénéen. Strata 21, Toulouse.

Perret MF, Weyant M (1994) Les biozones à conodontes du Carbonifère des Pyrénées. Comparaisons avec d'autres régions du globe. Geobios 27:689-715.

Perret MF, Joseph J, Mirouse R, Mouravieff A (1972) Un précieux jalon chronostratigraphique dans le Paléozoïque pyrénéen: la datation des "Calcaires rubanés" du Pic Larrue (Hautes Pyrénées). C R Acad Sci Paris D 274:2439-2442.

Pillola GL (1989) Données lithologiques et stratigraphiques sur le Cambrien et le Trémadoc de l'Iglesiente (SE de la Sardaigne). In : Sassi FP, Bourrouilh R (eds) IGCP Project no. 5, Correlation of Prevariscan and Variscan events of the Alpine-Mediterranean Mountain Belt. Newsletter 7, 228-239.

Pillola GL (1990) Lithologie et Trilobites du Cambrien inférieur du SW de la Sardaigne (Italie): implications paléobiogéographiques. C R Acad Sci Paris 310:321-328.

Pillola GL, Piras S, Serpagli E (2008) Upper Tremadoc-Lower Arenig? Anisograptid-Dichograptid fauna from the Cabitza Formation (Lower Ordovician, SW Sardinia, Italy). Rev Micropal 51:167-181.

Pitra P, Poujol M, Den Driessche JV, Poilvet JC, Paquette JL (2012) Early Permian extensional shearing of an Ordovician granite: The Saint-Eutrope "C/S-like" orthogneiss (Montagne Noire, French Massif Central). C R Géosci 344:377-384.

Plusquellec Y, Fernández-Martínez E, Sanz-López J, Soto F, Magrans J, Ferrer E (2007) Tabulate corals and stratigraphy of Lower Devonian and Mississippian rocks near Barcelona (Catalonian Coastal Ranges, Northeast Spain). Rev Esp Paleontol 22:175-192.

Poblet J (1991) Estructura herciniana i alpina del versant sud de la zona axial del Pirineu central. $\mathrm{PhD}$ thesis, Univ. Barcelona.

Poty E (2007) The Avins event: a remarkable worldwide spread of corals at the end of the Tournaisian (Lower Carboniferous). In Hubmann B, Piller WE (eds) Fossil corals and sponges. Graz 2003. Schriften erdwiss Komm (Oesterreichische Akad Wiss) 17, Wien, pp 231-250.

Puddu C, Casas JM (2011) New insights into the stratigraphy and structure of the Upper Ordovician rocks of the la Cerdanya area (Pyrenees). In: Gutiérrez-Marco JC, Rábano I, García-Bellido D (eds) Ordovician of the World. Cuad. Museo Geomin 14:441-445.

Pujadas J, Casas JM, Muñoz JA, Sàbat F (1989) Thrust tectonics and Paleogene syntectonic sedimentation in the Empordà area (southeastern Pyrenees). Geodin Acta 3:195-206.

Raymond D (1987) Le Dévonien et le Carbonifère inférieur du sud-ouest de la France (Pyrénées, Massif de Mouthoumet, Montagne Noire): sédimentation dans un bassin flexural en bordure sud de la Chaîne de collision varisque. Geol Rundsch 76:795-803.

Raymond D, Lethiers F (1990) Signification géodynamique de l'événement radiolaritique dinantien dans les zones externes sud-varisques (Sud de la France et Nord de l'Espagne). C R Acad Sci Paris 310:1263-1269.

Requadt H (1974) Aperçu sur la stratigraphie et le facies du Devonien inferieur et le moyen dans les Pyrénées Occidentales d'Espagne. Pirineos 111:109-127.

Robert JF (1980) Etude géologique et métallogénique du Val de Ribas sur le versant espagnol des Pyrénées Catalanes. PhD, Univ. Besançon.

Robert JF, Thiébaut J (1976) Découverte d'un volcanisme acide dans le Caradoc de la région de Ribes de Freser (Prov. de Gérone). C R Acad Sci, Paris 282:2050-2079.

Roger F, Respaut JP, Brunel M, Matte Ph, Paquette JL (2004) Première datation U-Pb des orthogneiss aillés de la zone axiale de la Montagne Noire (Sud du Massif central): nouveaux témoins du magmatisme ordovicien dans la chaîne varisque. C R Géosci 336:19-28.
Roqué Bernal J, Štorch P, Gutiérrez-Marco JC (2017) Bioestratigrafía (graptolitos) del límite Ordovícico-Silúrico en los Pirineos orientales (curso alto del río Segre, Lleida). Geogaceta 61:27-30.

Rudnick RL, Gao S (2004) Composition of the Continental Crust. In: Rudnick, RL (ed) The Crust. Treatise on Geochemistry. Holland HD, Turekian KK (eds), Elsevier-Pergamon, Oxford, 3:1-64.

Sánchez de Posada LC, Sanz-López J, Gozalo R (2008) Ostracod and conodont faunal changes across the Frasnian-Famennian boundary at Els Castells, Spanish central Pyrenees. Rev Micropal 51: 205-219.

Santanach PF (1972a) Sobre una discordancia en el Paleozoico inferior de los Pirineos orientales. Acta Geol Hisp 7:129-132.

Santanach PF (1972b) Estudio tectónico del Paleozoico inferior del Pirineo entre la Cerdaña y el río Ter. Acta Geol Hisp 7:44-49.

Sanz-López J (1995) Estratigrafía y bioestratigrafía (Conodontos) del Silúrico superior-Carbonífero inferior del Pirineo Oriental y Central. Dissertation, University of Barcelona.

Sanz-López J (2002a) Devonian and Carboniferous pre-Stephanian rocks from the Pyrenees. In: García-López S, Bastida F (eds) Palaeozoic conodonts from northern Spain. Eight International Conodont Symposium held in Europe. Publ IGME, Cuad Mus Geomine 1, Madrid, pp 367-389.

Sanz-López J (2002b) Devonian and Lower Carboniferous rocks from the Cadí nappe (eastern Pyrenees). In: García-López S, Bastida F (eds) Palaeozoic conodonts from northern Spain. Eight International Conodont Symposium held in Europe. Publ IGME, Cuad Mus Geomin, Madrid 1:419-438.

Sanz-López, J, Gil-Peña I, Rodríguez-Cañero R (2002c) Conodont content and stratigraphy of the Llessui Formation from the south central Pyrenees. In: García-López S, Bastida F (eds) Palaeozoic conodonts from northern Spain. Eight International Conodont Symposium held in Europe. Publ IGME, Cuad Mus Geomin 1, Madrid, pp 391-401.

Sanz-López J (2004) Silúrico, Devónico y Carbonífero pre- y sin-varisco en Geología de los Pirineos. In: Vera JA (ed.) Geología de España. SGE-IGME, Madrid, pp 250-254.

Sanz-López J, Blanco-Ferrera S (2012) Revisión estratigráfica del Misisipiense al Pensilvaniense más bajo de la zona Cantábrica y la posición de los límites entre los pisos. Geo-Temas 13:90 (annexed CD: 163-166).

Sanz-López J, Palau J (2000) Conodontos del Wenlock del macizo del Marimanya, Pirineo central. 1st Congr Iber Paleontol, 16th J Soc Esp Paleontol, Évora, pp 278-279.

Sanz-López J, Sarmiento GN (1995) Asociaciones de conodontos del Ashgill y del Llandovery en horizontes carbonatados del valle del Freser (Girona). 11th J Paleontol, Tremp, pp 157-160.

Sanz-López J, Valenzuela-Ríos JI, García-López S, Gil Peña I, Robador A (1999) Nota preliminar sobre la estratigrafía y el contenido en conodontos del Prídolí-Lochkoviense inferior en la unidad de els Castells (Pirineo central). Temas Geol-Min ITGE 26 (2), pp 638-642.

Schmidt H (1931) Das Paläozoikum der spanischen Pyrenäen. Abh Ges Wiss K 3 5, Göttingen.

Shervais J (1982) Ti-V plots and the petrogenesis of modern and ophiolitic lavas. Earth and Planetary Sci Letters 59:101-118.

Slavík L, Valenzuela-Ríos JI, Hladil J, Chadimová L, Liao J-C, Hušková A, Calvo H, Hrstka T (2016) Warming or cooling in the Pragian? Sedimentary record and petrophysical logs across the Lochkovian-Pragian boundary in the Spanish central Pyrenees: Palaeogeogr Palaeoclim Palaeocol 449, 300-320.

Speksnijder A (1986) Geological analysis of Paleozoic large-scale faulting in the south-central Pyrenees. Geol Ultraiectina 43.

Stampfli GM, von Raumer JF, Borel GD (2002) Paleozoic evolution of pre-Variscan terranes: from Gondwana to the Variscan collision. In: Martínez Catalán JR, Hatcher RD, Arenas R, Díaz García F 
(eds) Variscan-Appalachian Dynamics: the Building of the Late Paleozoic Basement. Geol Soc Am, Spec Pap 364:263-280. Boulder, Colorado.

Sun SS, McDonough WF (1989) Chemical and isotopic systematics of oceanic basalts; implications for mantle composition and processes. In: Saunders AD, Norry MJ (eds) Magmatism in the Ocean Basins. Geol Soc London, Spec Vol 42: 429-448.

Syme EC (1998) Ore-associated and barren rhyolites in the central Flin Flon Belt: Case study of the Flin Flon mine sequence. Manitoba Energy and Mines, Open File Rep OF98-9:1-32.

Vachard D, Cózar P, Aretz M, Izart A (2016) Late Viséan-Serpukhovian foraminifers in the Montagne Noire (France): Biostratigraphic revision and correlation with the Russian substages. Geobios 49:469-498.

Valenzuela-Ríos JI, Slavík L, Liao J-C, Calvo H, Hušková A, Chadimová L (2015) The middle and upper Lochkovian (Lower
Devonian) conodont successions in key peri-Gondwana localities (Spanish Central Pyrenees and Prague Synform) and their relevance for global correlations. Terra Nova 27:409-415.

Walliser OH (1996) Global events in the Devonian and Carboniferous, In: Walliser $\mathrm{OH}$ (ed) Global events and event stratigraphy in the Phanerozoic. Springer-Verlag, Berlin, pp 225-250.

Wirth M (1967) Zur Gliederung des höheren Paläozoikums (Givet-Namur) im Gebiet des Quinto Real (West pyrenäen) mit Hilfe von Conodonten). N J Geol Palaeont Abh 127:179-244.

Wood D (1980) The application of a Th-Hf-Ta diagram to problems of tectonomagmatic classification and to establishing the nature of crustal contamination of basaltic lavas of the British Tertiary volcanic province. Earth Planet Sci Lett 50:11-30.

Zwart HJ (1979) The Geology of the Central Pyrenees. Leidse Geol Meded 50:1-74. 